\title{
Emerging Diagnostics for Transplant Infectious Diseases
}

\author{
Marwan M. Azar, David C. Gaston, and Maricar F. Malinis
}

\section{Contents}

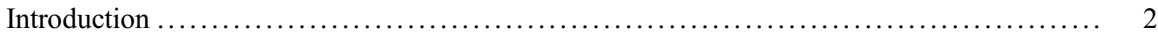

Epidemiology and Impact of Antimicrobial Resistance in Transplant Populations ........ 3

Emerging Diagnostics for Bloodstream Infections ................................ 4

Molecular Methods Performed on Positive Blood Culture Bottles ................... 4

Molecular Methods Performed on Blood Specimens ............................ 16

Impact of Rapid Molecular Diagnostics on Clinical Outcomes in Transplant

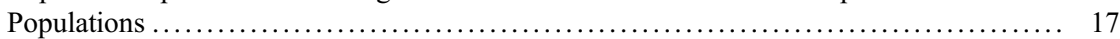

Magnetic Resonance-Based Methods ..................................... 18

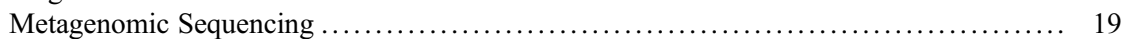

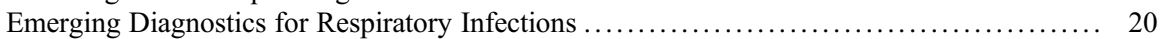

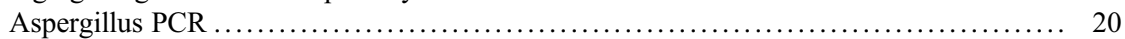

Aspergillus PCR for Diagnosis of Resistance in Aspergillus Species ................. 26

Gas Chromatography-Mass Spectrometry of Exhaled Metabolites .................. 27

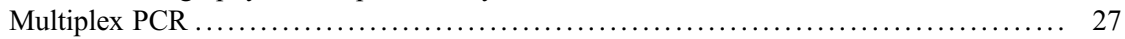

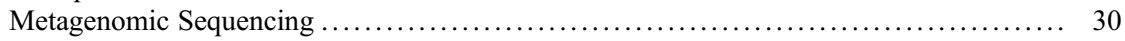

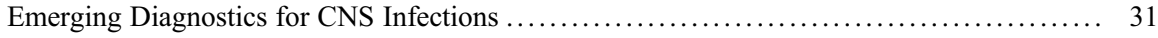

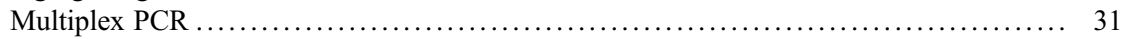

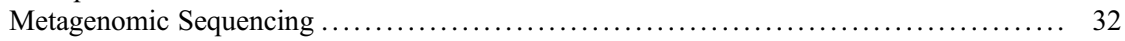

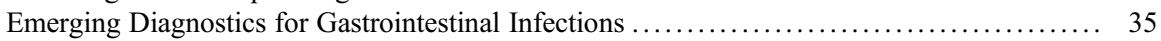

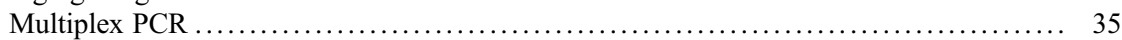

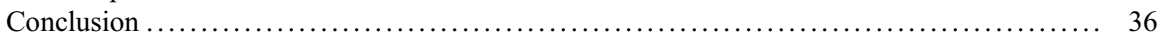

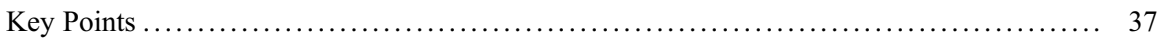

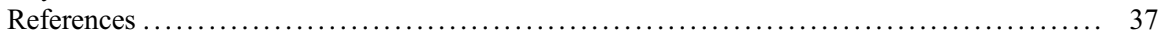

M. M. Azar $(\bowtie) \cdot$ D. C. Gaston

Department of Internal Medicine, Section of Infectious Diseases, Yale School of Medicine, New Haven, CT, USA

e-mail: marwan.azar@yale.edu; david.gaston@yale.edu

M. F. Malinis

Department of Internal Medicine, Section of Infectious Diseases, Yale School of Medicine, New Haven, CT, USA

Department of Surgery, Yale School of Medicine, New Haven, CT, USA

e-mail: maricar.malinis@yale.edu 


\begin{abstract}
Following solid organ and hematopoietic stem cell transplantation, patients are at increased risk for community-acquired infections, opportunistic and uncommon pathogens, coinfections, and multidrug-resistant organisms. Given the increased predilection for serious infection in this population, diagnostics applicable to the practice of transplant infectious diseases are essential. In the last decade, diagnostic microbiology has witnessed a shift toward culture-independent methods such as molecular testing, mass spectrometry, and magnetic resonance-based technologies that have greatly increased diagnostic capabilities. More recently, another wave of diagnostic modalities including highly multiplexed polymerase chain reaction (PCR) panels directly applicable to clinical specimens and with the potential for resistance detection, metagenomic sequencing, and breath-based diagnosis of volatile metabolites has emerged with significant potential for transplant infectious diseases. At present, many of these technologies continue to have certain drawbacks that limit their applicability, but despite shortcomings, emerging technologies have already demonstrated a diagnostic advantage and a positive impact on patient outcomes. Though data on test performance characteristics and clinical impact among transplant patients remains scarce, it is likely that these modalities will translate into even greater utility given the increased risk for infection in this population. In this review, we examine emerging diagnostic methods for infectious diseases with a focus on the application to transplant patients.
\end{abstract}

\title{
Keywords
}

Transplant $\cdot$ Diagnostics $\cdot$ Molecular $\cdot$ Metagenomic sequencing $\cdot$ Emerging · Magnetic resonance $\cdot$ Multiplex $\cdot \mathrm{PCR} \cdot$ Exhaled $\cdot$ Metabolites $\cdot$ Sensitivity

\section{Introduction}

Following solid organ and hematopoietic stem cell transplantation, innate and adaptive immune responses are significantly impaired, placing patients at high risk for infections with both community-acquired and opportunistic pathogens. In contrast to the general population, immunocompromised hosts often develop infections with multiple pathogens at once or with uncommon pathogens for which currently available conventional diagnostics are suboptimal. Owing to prolonged hospitalizations and greater exposure to antimicrobials, transplant recipients patients are also at higher risk for acquisition of multidrug-resistant (MDR) organisms. In light of the increased vulnerability to infection, diagnostics applicable to the practice of transplant infectious diseases are essential. Though culture and histopathology remain a bedrock of diagnosis, diagnostic microbiology has witnessed immense progress in the last decade, including a shift toward culture-independent methods such as molecular testing, mass spectrometry, and magnetic resonance-based technologies. Such methods have greatly expanded the array of organisms identified, enhanced the 
detection of resistance determinants, significantly shortened the time to diagnosis, and positively impacted the care of transplant patients with infections. On the horizon is another wave of diagnostic modalities with immense potential to enhance our diagnostic capabilities for transplant infectious diseases including highly multiplexed polymerase chain reaction (PCR) panels directly applicable to clinical specimens and with the potential for resistance detection, metagenomic next-generation sequencing (mNGS), and breath-based diagnosis of volatile metabolites among others. In this review, we examine emerging diagnostic methods for infectious diseases with a focus on the application to transplant patients.

\section{Epidemiology and Impact of Antimicrobial Resistance in Transplant Populations}

The emergence and spread of MDR organisms in the last decade have imposed an enormous clinical burden on patient populations worldwide. Partially a result of systematic misuse and overuse of available antibiotics, the crisis of antimicrobial resistance has been compounded by diminished antibiotic drug development, leading to a severely restricted antimicrobial armamentarium to treat MDR organisms. At the turn of the twenty-first century, infections with resistant Gram-positive organisms including methicillin-resistant Staphylococcus aureus (MRSA) and vancomycin-resistant Enterococcus (VRE) predominated as the foremost causes of nosocomial infections, with strains of vancomycin-intermediate $S$. aureus (VISA) now encountered worldwide [1]. In the last decade, however, MDR Gram-negative infections, driven by extended-spectrum beta-lactamase (ESBL) producing and carbapenem-resistant Enterobacteriaceae (CRE), have emerged as a serious threat to hospitalized patients. The negative impact of increasing multidrug resistance has been most pronounced among certain subsets of patients, including the critically ill and immunosuppressed, for whom ineffective empiric antibiotic therapy is strongly correlated with increased mortality [2]. Recipients of solid organ transplantation (SOT) and hematopoietic stem cell transplantation (HSCT) are particularly vulnerable to MDR infections due to underlying chronic disease, extended and recurrent hospitalizations, use of immunosuppressive modalities, ubiquity of intravascular catheters, risk of surgical site infections, repeated exposure to antimicrobials, and, in some cases, acquisition of donor-derived pathogens [3, 4]. Within transplant populations, allogeneic HSCT and heart and lung transplantation are associated with higher rates of resistance in Gram-negative bacteria, likely as a result of the aforementioned factors, including more intense immunosuppression [5, 6]. Resistance presents challenges to the selection of antibacterial prophylaxis and both empiric and targeted treatment modalities in any setting. Yet these are significantly amplified in the context of transplantation due to drug-drug interactions and poor baseline vital organ function which further limit antibiotic choices. Indeed, infections with drug-resistant organisms including MRSA, ESBL, CRE, Pseudomonas, Burkholderia, Stenotrophomonas, and Acinetobacter species have been associated with increased mortality for kidney, liver, and lung SOT and HSCT [5-9]. In parallel 
with the continued threat of bacterial resistance, drug-resistant fungi have become an important public health concern. Candida species are now the fifth most common nosocomial pathogen and a leading cause of mortality for transplant patients, especially in liver transplantation [10]. Recent years have seen the emergence of C. auris, an organism with the potential for resistance to all three major classes of antifungals (azoles, echinocandins, polyenes), and a proclivity for environmental persistence and nosocomial transmission including the possibility of donor-derived acquisition [11-13].

Since transplant patients with bacteremia or fungemia are at significantly higher risk for mortality than other populations, with a risk of death of up to $60 \%$ by some assessments, prompt identification of bloodstream pathogens is crucial in timely administration of effective antimicrobial therapy [24, 14].

\section{Emerging Diagnostics for Bloodstream Infections}

In the last decade, molecular-based diagnostics that rapidly identify bloodstream pathogens and their resistance determinants directly from positive blood cultures and on blood samples have been developed. These assays, along with non-PCR-based methods such as magnetic resonance and metagenomics, hold significant promise for improving diagnostic yield and ultimately outcomes of transplant patients.

\section{Molecular Methods Performed on Positive Blood Culture Bottles}

Rapid identification and antimicrobial susceptibility testing (AST) for bloodstream pathogens are critical in transitioning empiric to directed antimicrobial therapy, a key step in optimizing patient outcomes in the setting of sepsis. In traditional laboratory schemes, organism identification takes 48 hours or longer, and results of AST require an additional 24 hours at least [15]. Such delays in the identification of bloodstream pathogens prompt treating clinicians to select empiric antimicrobial therapy for anticipated infecting pathogens based on the clinical syndrome and host, as well as local or facility-specific antimicrobial resistance patterns for selected pathogens. However, empiric therapy based on estimation of pretest probability is very often incorrect, with up to $50 \%$ of patients with bacteremia and up to $70 \%$ of patients with fungemia receiving inadequate empiric treatment prior to resulting of culture data $[16,24]$. To circumvent the inherent delays associated with this testing paradigm, several molecular-based rapid diagnostic tests have been developed in an attempt to directly identify organisms from positive blood culture broth and provide resistance information without the need for culture. These techniques have the capacity to identify specific organisms (to the species or genus level) or groups of organisms. Importantly, many methods provide additional direct genotypic resistance information by identifying specific genetic determinants associated with phenotypic resistance, such as the mecA gene that confers methicillin resistance in S. aureus or direct phenotypic resistance data by providing extrapolated minimal inhibitory 


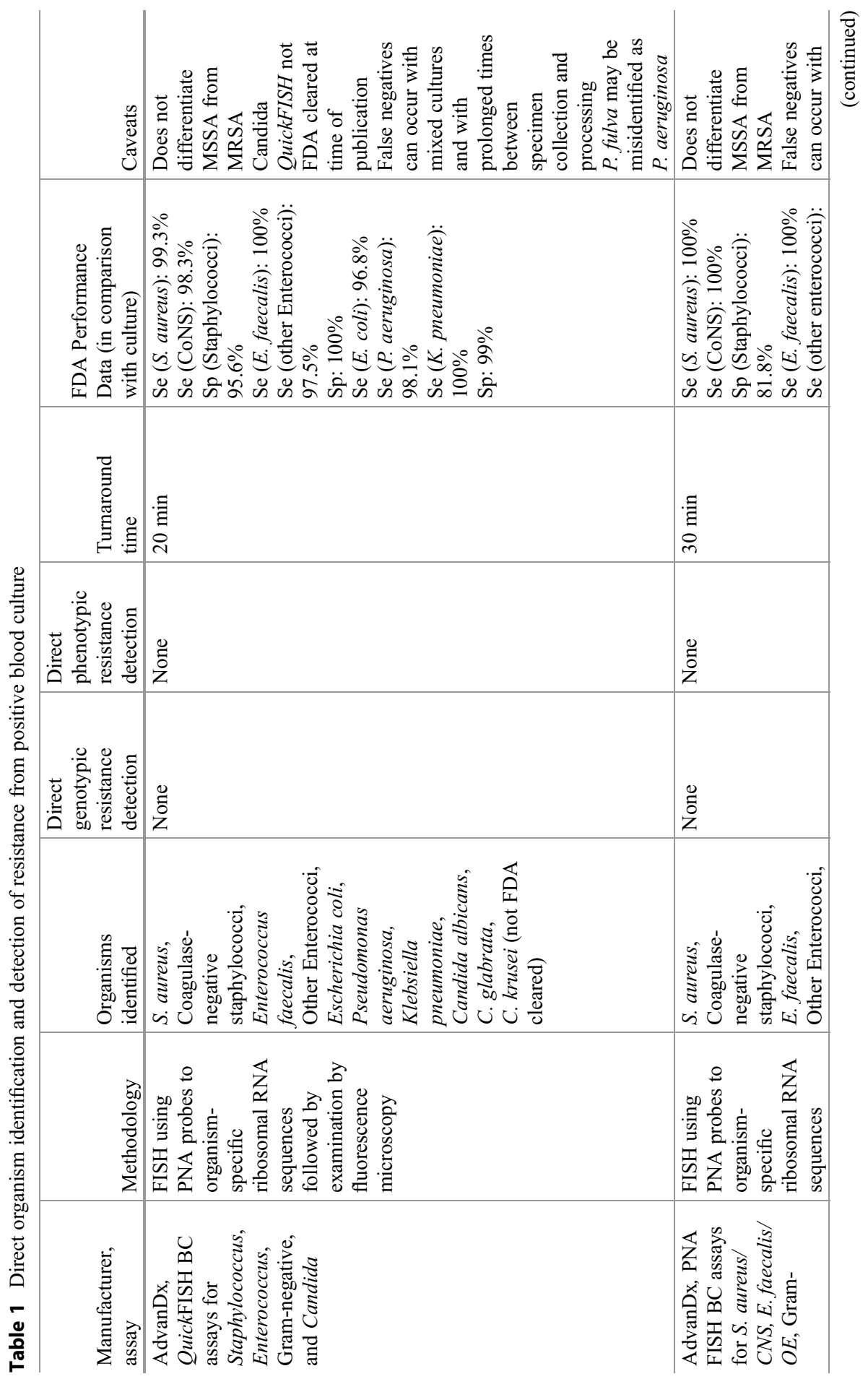




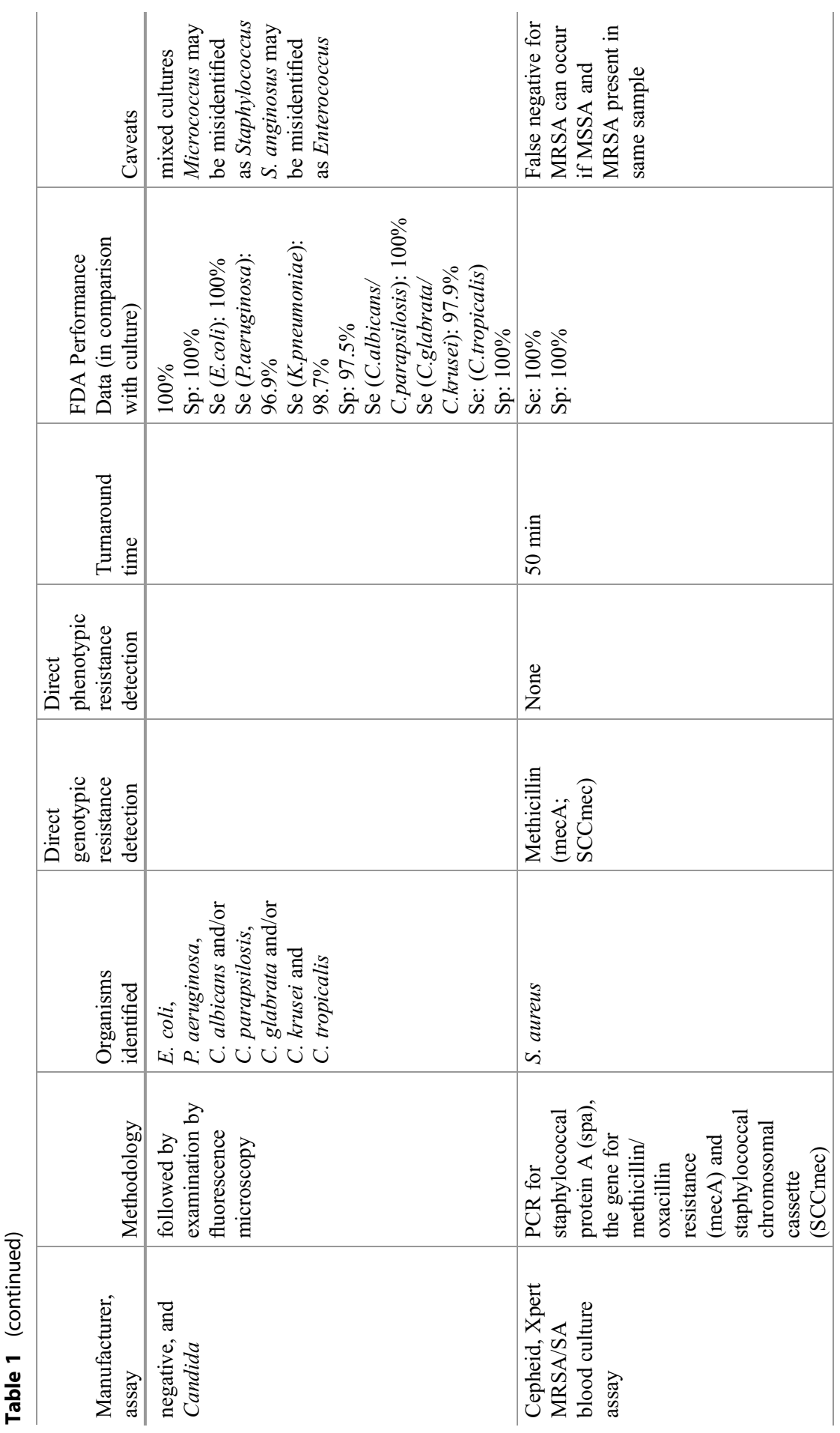




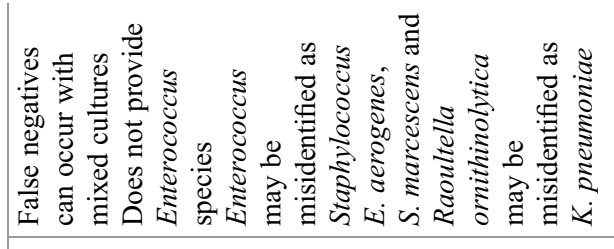

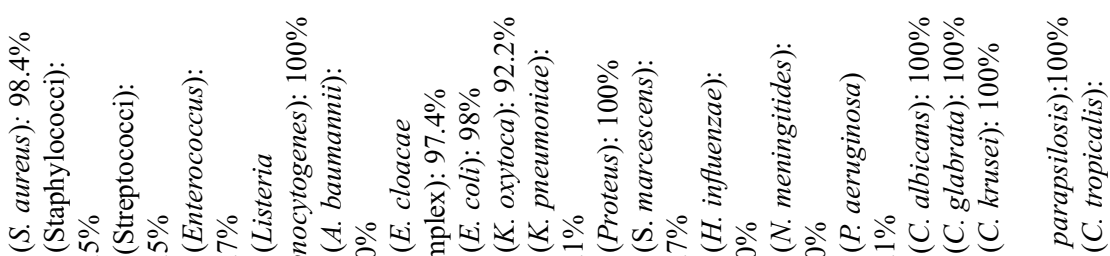

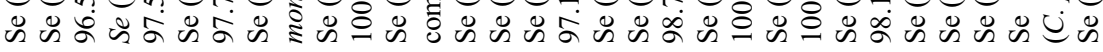

工

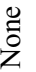
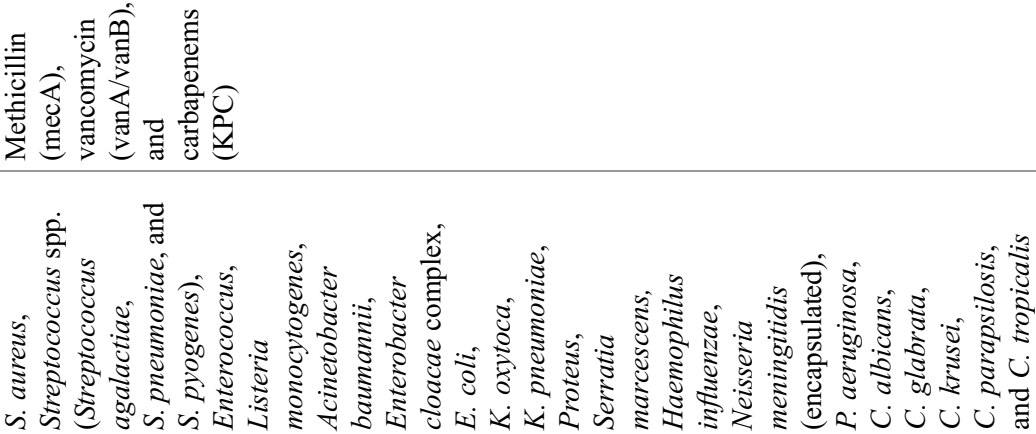

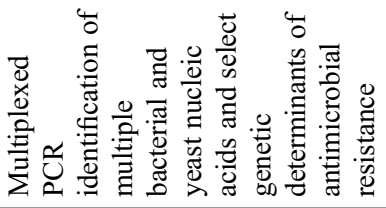

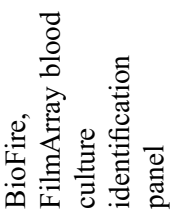




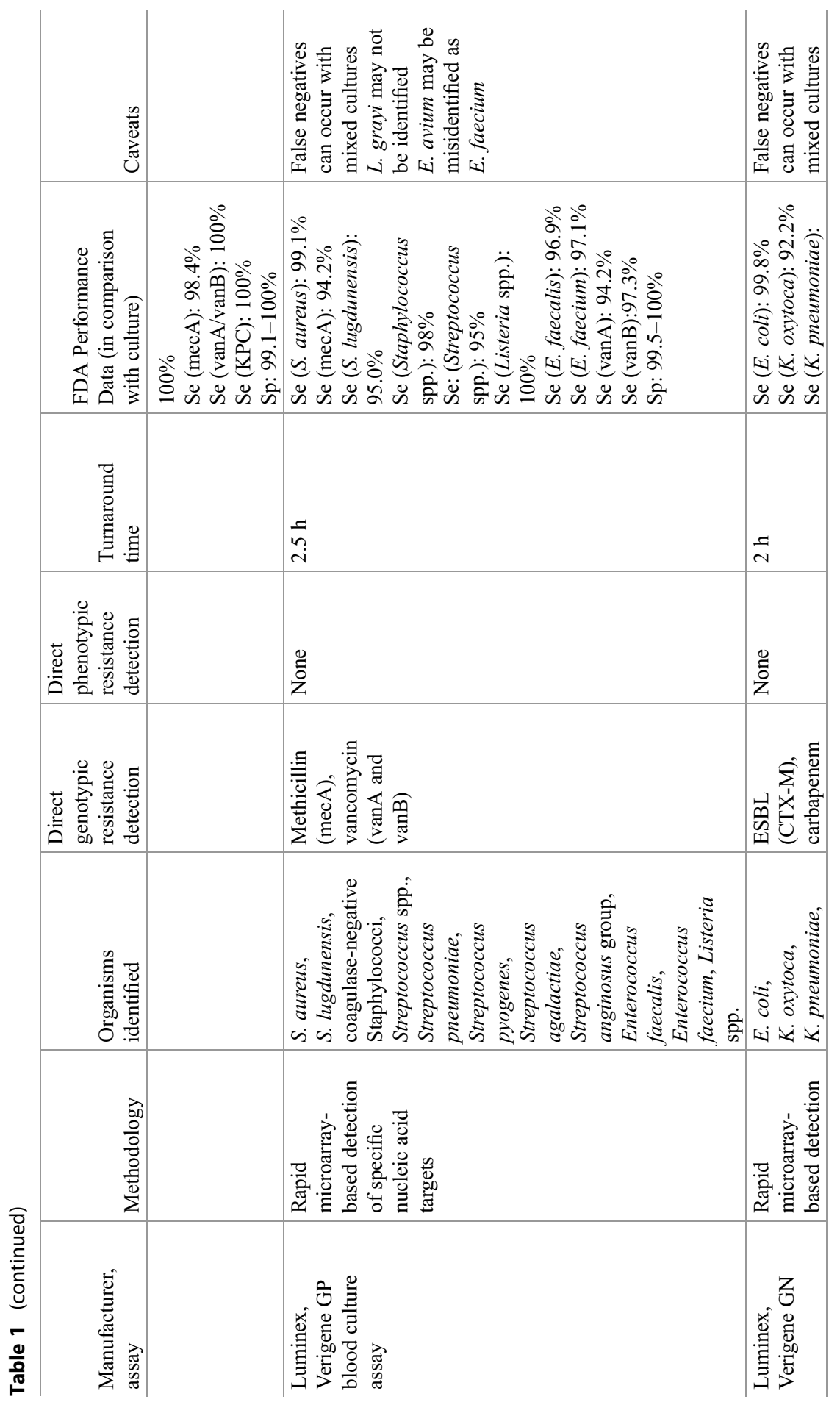




\begin{tabular}{|c|c|}
\hline 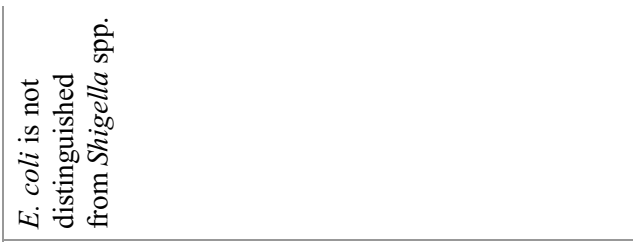 & 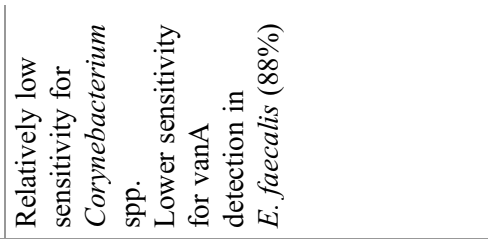 \\
\hline 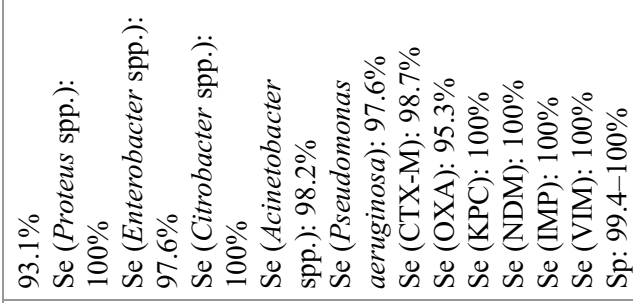 & 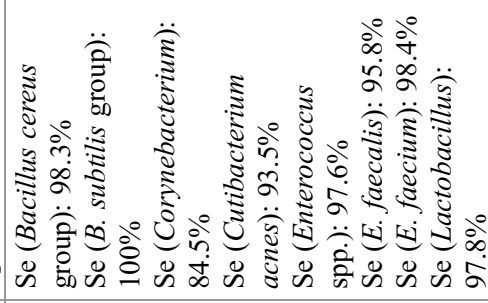 \\
\hline & 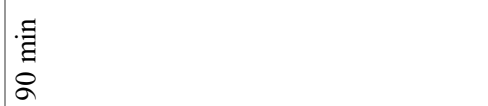 \\
\hline & 芒 \\
\hline 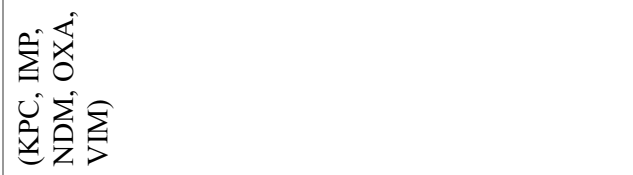 & 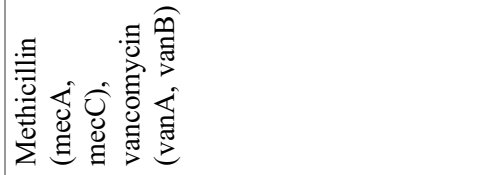 \\
\hline 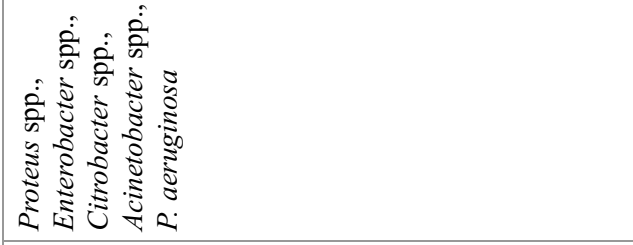 & 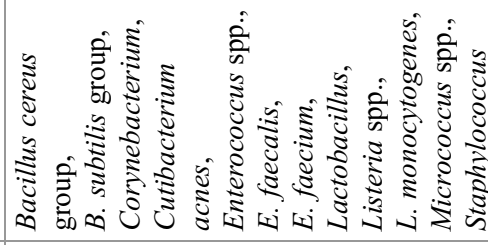 \\
\hline 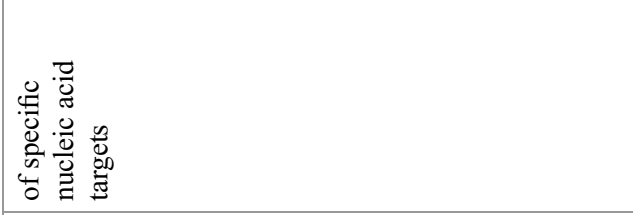 & 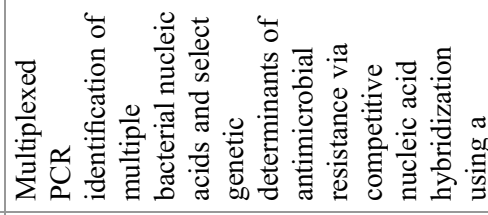 \\
\hline 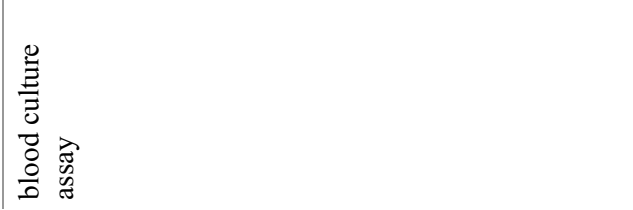 & 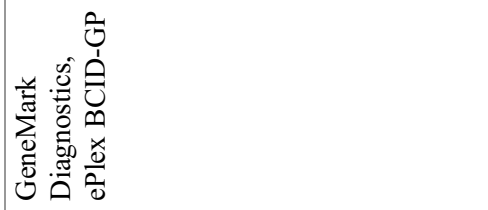 \\
\hline
\end{tabular}




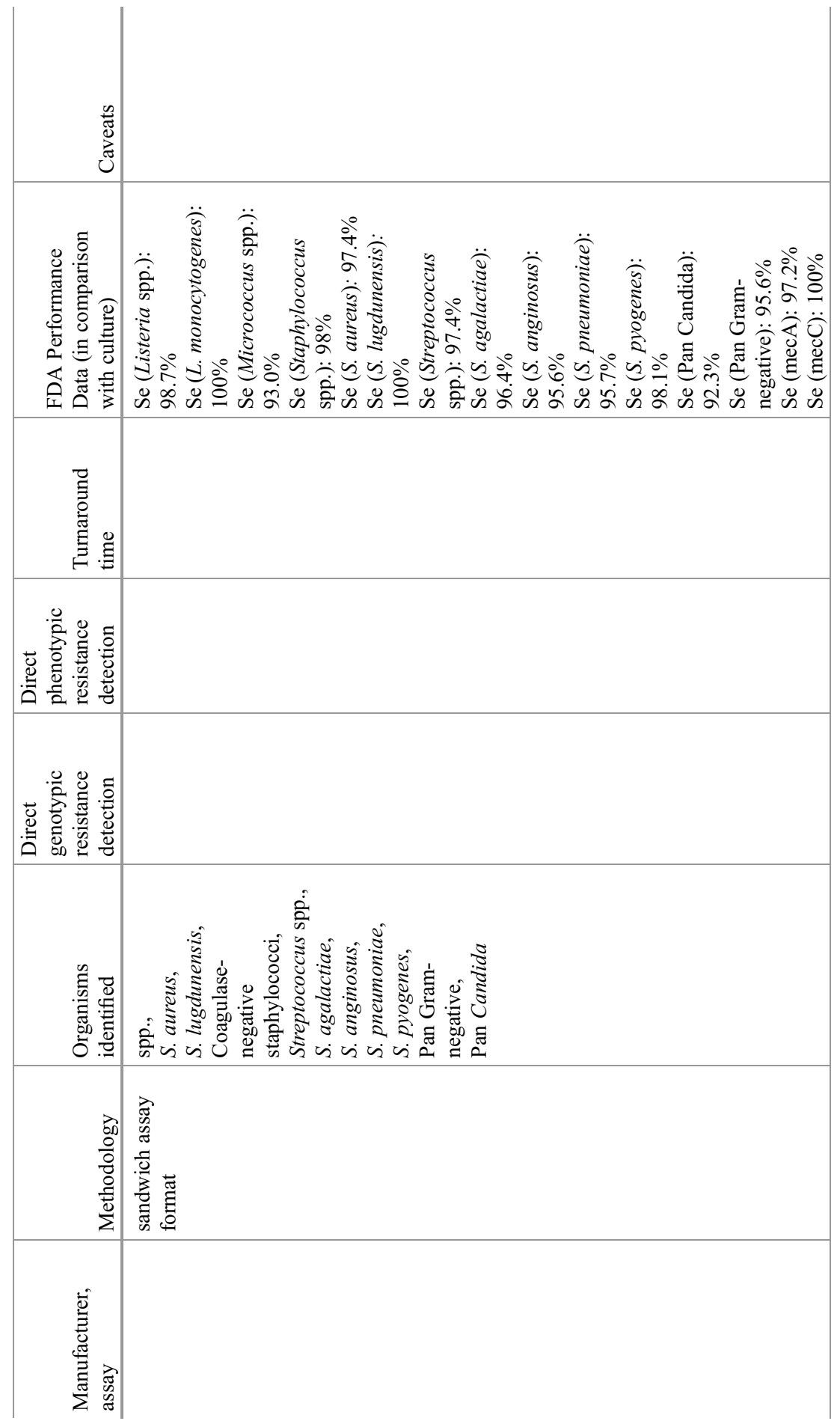




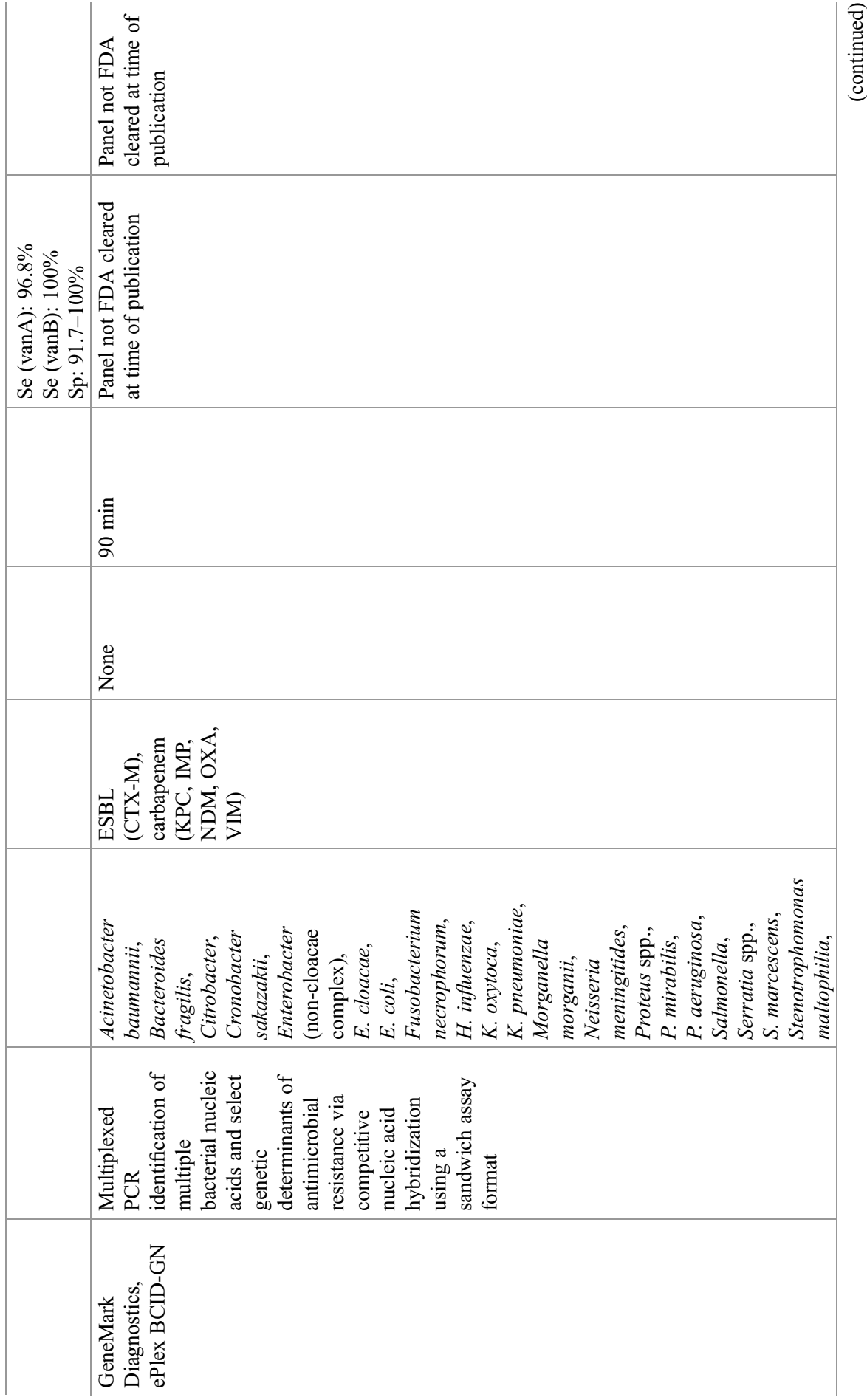




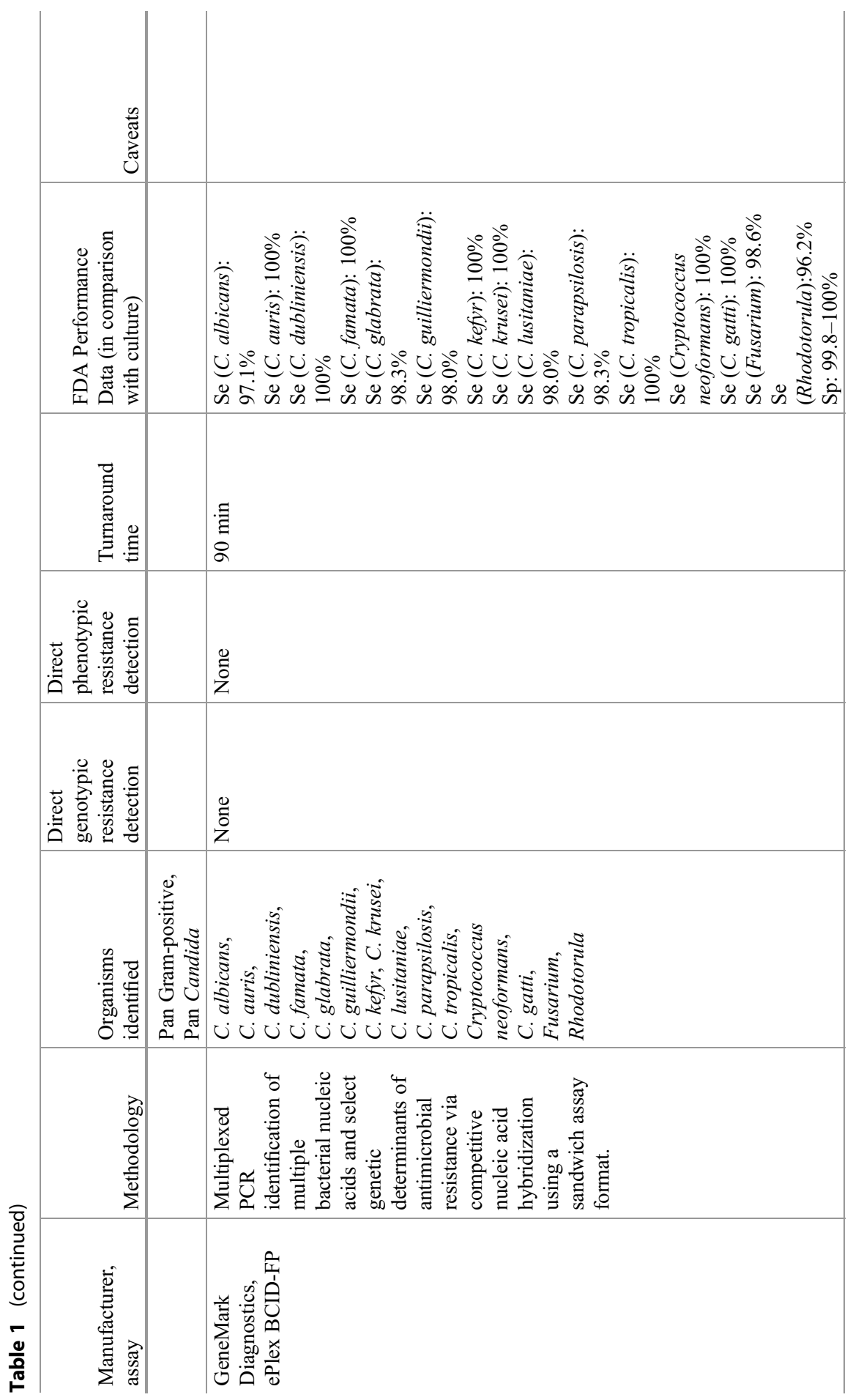




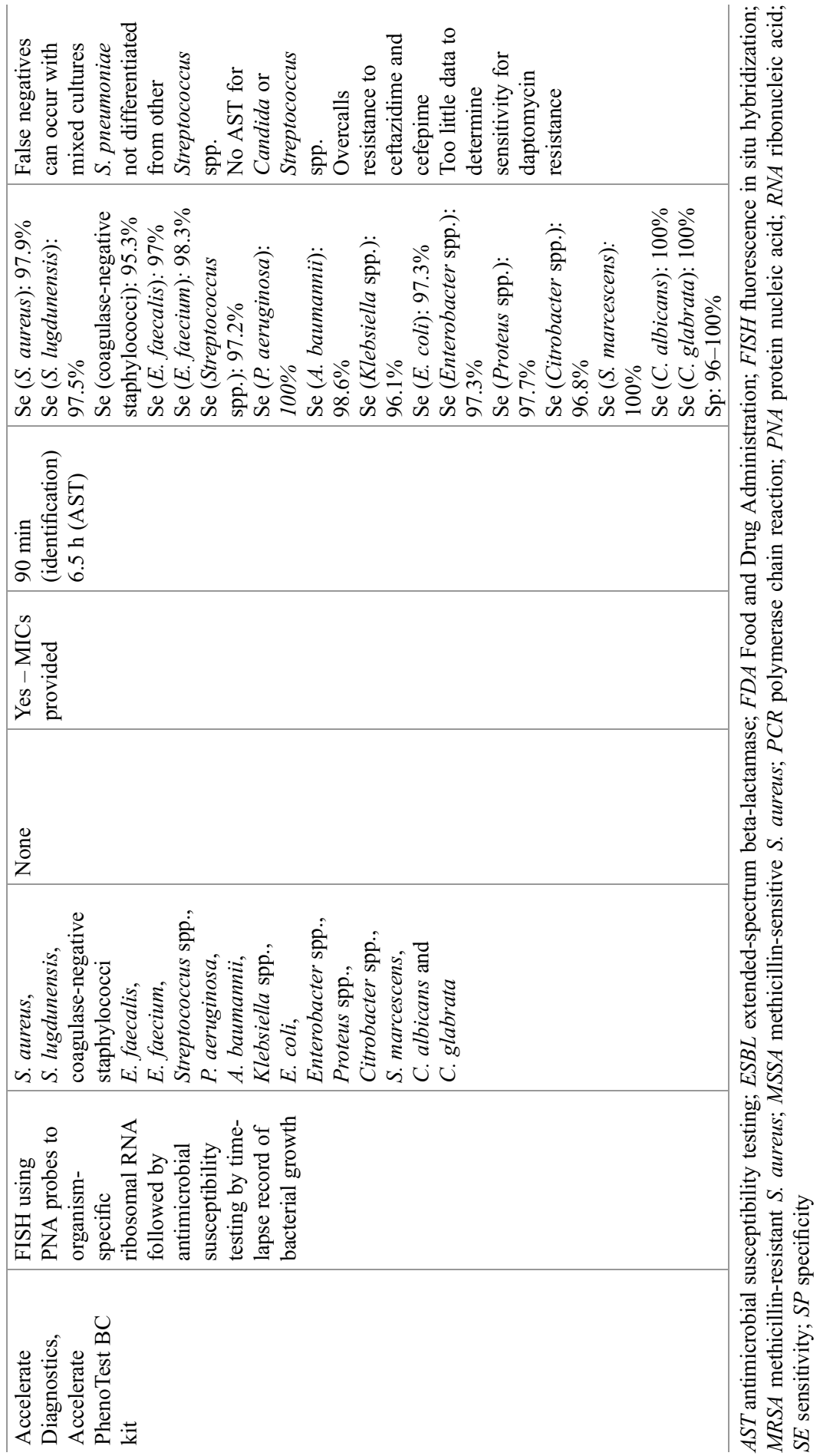


concentration (MIC) for specific antimicrobials. These molecular assays are considered moderate in terms of user complexity but benefit from minimal sample processing and hands-on time as well as automated test interpretation. Though little data exists in the context of transplant patients, these assays hold significant promise to accelerate diagnosis and resistance detection for this vulnerable population.

Several FDA-cleared rapid molecular tests for direct organism and resistant detection from blood culture are currently commercially available in the United States (Table 1). The QuickFISH and PNA FISH BC assays (OpGen, Maryland, USA, previously AdvanDx) for Staphylococcus, Enterococcus, Gram-negative, and Candida (Candida QuickFISH not FDA cleared at time of this writing) employ fluorescence in situ hybridization (FISH) using nucleic acid probes to identify organism-specific ribosomal RNA sequences, followed by automated examination and quantification under fluorescence microscopy, within a turnaround time of 2.5 hours and 20-30 minutes, respectively. The Gram-negative organisms identified are limited to Escherichia coli, P. aeruginosa, and Klebsiella pneumoniae, and Candida species are categorized into groups (C. albicans/C. parapsilosis, $C$. glabrata/C. krusei, and C. tropicalis). No AST information is provided using this assay; importantly the method does not differentiate between MRSA and methicillin-sensitive $S$. aureus (MSSA). Other limitations include the high limit of detection of $10^{5} \mathrm{CFU} / \mathrm{mL}$ and the possibility of false negatives with prolonged times between specimen collection and processing. With the PNA FISH assay, Micrococcus may be misidentified as Staphylococcus, and S. anginosus may be misidentified as Enterococcus.

The Xpert MRSA/SA blood culture assay by Cepheid (Carlsbad, USA) identifies $S$. aureus from positive blood cultures within a 50-minute time frame. Using PCR, the assay detects DNA sequences for staphylococcal protein A ( $\mathrm{SpA})$ as well as staphylococcal chromosomal cassette (SCCmec) and mecA, genes specific to MRSA. This assay therefore provides some resistance information to guide directed treatment of $S$. aureus bacteremia. Test sensitivity in FDA trial data was reported at $100 \%$, but real-world incidence of false negatives $(\sim 0.5-1 \%)$ can be significant in a high-volume center and has the potential to lead to inappropriate narrowing of empiric antibiotics, so internal verification of the assay and ongoing surveillance for false negatives should be performed [17]. False negatives may occur with novel or rare MRSA strains whose resistance is based on variant resistance genes (such as $m e c C)$ and in cases of coinfection with MSSA and MRSA.

The FilmArray (bioMerieux, France, Biofire Diagnostics, USA) blood culture identification panel utilizes multiplex PCR to detect bacterial and yeast nucleic acids specific to S. aureus, Streptococci, Enterococcus, Listeria, Enterobacteriales, Acinetobacter, Pseudomonas, Hemophilus influenzae, and Candida species in a turnaround time of 1 hour. In previous iterations, only one sample could be processed at a time, but a new version of the instrument (FilmArray Torch) allows for much greater throughput. Select genetic determinants of antimicrobial resistance are provided including methicillin ( $m e c A)$, vancomycin (van $A / B)$, and carbapenems (KPC). The assay delivers species identification for the five most clinically important Candida species. Species level identification for Enterococcus is not provided, and 
this genus may be misidentified as Staphylococcus. False-positive detection of the $m e c A$ gene in Staphylococci can occur.

The Verigene GP and GN assays (Luminex Corporation, USA) employ a microarray-based detection of specific nucleic acid targets whereby specific target sequences within the clinical sample bind to capture probes in defined spots on a microarray plate. Probe-target hybridization is detected and quantified by detection of gold-labeled targets to determine relative abundance of nucleic acid sequences in the target. The GP and GN assays are associated with turnaround times of 2.5 and 2 hours, respectively. Gram-positive organisms identified include $S$. aureus and coagulase-negative Staphylococci (including $S$. lugdunensis), Streptococci including S. pneumonia, E. faecalis, and E. faecium, and Listeria species. The GP assay also detects genetic markers of resistance including mecA, vanA, and vanB. Gramnegative organisms include several species of Enterobacteriacae, $P$. aeruginosa, and Acinetobacter species. The GN assay further detects genes associated with ESBL (CTX-M) and carbapenemase production (KPC, IMP, NDM, OXA, VIM). Notably, the assay does not distinguish $E$. coli from Shigella species.

The recently FDA-approved ePlex (GenMarkDx., Carlsbad, USA) blood culture identification (BCID) panels by GenMark Diagnostics provides a more expansive coverage of infecting pathogens than other commercial tests, with a similar turnaround time $(90 \mathrm{~min})$ and a considerable throughout capacity of 244 patient samples in a 24-hour period. The assay is based on nucleic acid amplification followed by competitive DNA hybridization and electrochemical detection. In addition to common Gram-positive pathogens, the BCID-GP panel includes Bacillus, Lactobacillus, Cutibacterium acnes (formerly Propionibacterium acnes), and Corynebacterium species. The Gram-negative panel (BCID-GN), which is undergoing FDA review at the time of this writing, includes an expanded array of organisms including anaerobes (Fusobacterium, Bacteroides), Cronobacter, and Stenotrophomonas maltophilia. The fungal pathogen panel (BCID-FP) includes an array of clinically important Candida species. This includes $C$. auris, as well as other clinically important yeast (Cryptococcus, Rhodotorula) and molds (Fusarium) that are significant causes of disease in transplant populations. In addition to common resistance determinants, ePlex BCID-GP detects $m e c C$, a novel mecA homologue encoding for a variant penicillin-binding protein (PBP2a). Real-world experience using the ePlex assays will be important in defining its utility and identifying potential caveats.

The Accelerate PhenoTest BC kit (Accelerate Diagnostics, Arizona, USA) represents the first FDA-approved rapid molecular test on blood that provides phenotypic resistance information in addition to organism identification directly from blood culture. The assay employs FISH-based technology for identification, which is obtained within 90 minutes. While FISH identification is underway, remaining clinical sample is combined with growth media in individual flow cells containing single concentrations of each test antibiotic. The cell morphology and light intensity of growing bacteria in each flow cell are imaged every 10 minutes for up to 4.5 hours, creating a time-lapse record of bacterial growth. Software algorithms then derive MIC values and apply appropriate interpretive criteria, delivering AST information approximately 5 hours after identifying the infecting pathogens. The 
array of organisms identified is comparable to some of the other genotypic methods, including the Verigene. The assay does not differentiate $S$. pneumoniae from other Streptococcus species. No AST is provided for Streptococcus or Candida species, and resistance to ceftazidime and cefepime may be overestimated. The assay achieved essential and categorical agreements of $>95 \%$ in comparison with Vitek 2 (bioMerieux), a routine identification and AST method used in clinical laboratories in the United States [18].

For all the aforementioned assays, false negatives may occur in the setting of polymicrobial bacteremia, though the FilmArray and ePlex assays perform better in this setting, a Gram stain of blood culture broth must be used for confirmation.

\section{Molecular Methods Performed on Blood Specimens}

Molecular methods performed directly on whole blood specimens rather than on positive blood culture broth have several potential advantages. By eliminating the need for a growth phase, they allow for more rapid identification of bloodstream pathogens and are less susceptible to poor organism growth as with fastidious or unculturable organisms or growth inhibition from antimicrobials. Such methods also require lower volumes of blood compared to assays based on blood culture collection [19]. There are currently no FDA-approved molecular methods for direct BSI identification in the United States, but several are available in Europe and Asia. Among these, the LightCycler SeptiFast (Roche Molecular System, Basel, Switzerland) identifies 19 bacterial and 6 fungal pathogens directly from whole blood (1.5 mL sample) with a turnaround time of 6 hours. The assay is based on detection of ITS regions within ribosomal DNA via fluorescence resonance energy transfer probes. This method demonstrated higher positivity rates than blood culture in immunocompromised patients including organ transplant recipients but lower rates in normal hosts with endocarditis [20]. The SepsiTest (Molzym, Bremen, Germany) identifies a vast array of pathogens including bacteria, fungi (including molds and yeast), and parasites (Plasmodium spp.) within 8-12 hours via broad range PCR of ribosomal DNA followed by sequencing. The assay achieved a sensitivity and specificity of 87.0 and $85.8 \%$, respectively, in comparison to blood cultures in a multicenter study [21]. The Magicplex ${ }^{\mathrm{TM}}$ Sepsis Real-time Test (Seegene, Seoul, Korea) similarly targets a wide panel of pathogens as well as three resistance determinants (vanA, vanB, and $m e c A$ ) and is applied directly to $1 \mathrm{~mL}$ of whole blood. The assay has not been well evaluated in transplant population but was poorly sensitive in comparison to blood culture in one study [22].

Methods that are directly applied to whole blood have several inherent disadvantages. First, diagnostic sensitivity is often suboptimal due to low bacterial concentration in whole blood and the low specimen volumes $(\sim 1 \mathrm{~mL})$ processed by these assays as compared to blood culture $(\sim 10 \mathrm{~mL})$. Second, high concentrations of human DNA and other blood constituents can act as interfering factors for PCRbased amplification, yielding false-negative results. Third, in the absence of growth 
amplification of live organisms, contaminating DNA or residual DNA from killed organisms may be preferentially amplified leading to false-positive results [19].

\section{Impact of Rapid Molecular Diagnostics on Clinical Outcomes in Transplant Populations}

For patients with bloodstream infections, the implementation of rapid molecular diagnostics on positive blood culture into standard microbiology practices reduces the time to targeted therapy as compared to routine microbiology techniques [23]. When combined with direct communication of results to treating clinicians and pharmacists, these assays are also associated with a significant reduction in mortality $[24,25]$. Implementing rapid testing in conjunction with antimicrobial stewardship programs further reduces time to antimicrobial de-escalation, decreasing exposure to unnecessarily broad antibiotics [26]. This results in decreased selective pressure, a key driver of antimicrobial resistance, and reduces cost associated with antimicrobial treatment, lengths of hospitalization, and overall healthcare expenses [27]. Evidence for improved outcomes among transplant patients is limited as most studies either include this subpopulation as part of broader analyses or exclude them from stewardship interventions $[23,28]$. However, since transplant patients are at increased risk for developing infections with MDR organisms as compared to other patient populations, they are at higher risk of receiving empiric therapy that does not have activity against highly resistant organisms. Transplant patients are also at higher risk for morbidity and mortality resulting from inadequate empiric therapy for bloodstream infections. Therefore, this population is conceivably more likely to benefit from the use of rapid molecular diagnostics than other groups [29]. Immunosuppressed patients are also more likely to develop infections with opportunistic pathogens encompassed within testing panels but for which traditional microbiologic identification is slow or suboptimal. This is particularly true for bloodstream infections due to fungi, especially Candida species, which are more common in SOT and HSCT populations. Since conventional blood culture methods for candidemia are only 50\% sensitive and Candida species often require an additional $24-48$ hours to grow, the diagnosis is very often missed or delayed, with expected negative effects on clinical outcomes [30]. Several assays encompass targets for the most common clinically important Candida species, including $C$. albicans and C. glabrata, while newer assays now include $C$. auris, an emerging pathogen associated with high mortality in immunocompromised patients and for which microbial identification with traditional diagnostic methods is challenging $[12,31]$. Rapid molecular tests on blood or positive blood culture bottles carry the potential to revolutionize the management of candidemia in transplant populations by improving the sensitivity of detection, reducing time to diagnosis and ultimately leveraging results to guide initiation and selection of appropriate antifungal therapy. Since rapid molecular tests were validated against blood cultures in FDA trial data, additional studies will be needed to determine if they can surpass the sensitivity of this "gold standard" and uncover the "missing 50\% of invasive candidiasis" [30]. 


\section{Magnetic Resonance-Based Methods}

The T2MR platform (T2 Biosystems, Lexington, MA) detects genetic material directly from blood samples using PCR amplification of fungal and bacterial nucleic acid followed by measurement of T2 magnetic resonance emanating from DNA probe complexes [32]. The platform is a non-culture-based stand-alone device, validated for whole blood specimens, and provides results within a 4-hour time frame. At present, two panels (T2Candida and T2Bacteria) are commercially available for clinical use, while a T2Candida auris panel is currently designated as research use only (RUO). T2 assays represent significant progress in the ability to directly detect pathogens from blood without the need for culture and carry the potential to reduce the time to diagnosis of bloodstream infections, an important cause of morbidity and mortality in the transplant population.

The T2Candida panel detects five clinically significant Candida species, including C. albicans, C. glabrata, C. krusei, C. parapsilosis, and C. tropicalis with the amplification step targeting internal transcribed spacer 2 (ITS2) rDNA. The assay does not provide resistance information other than susceptibility patterns inferred from species level identification. In a multicenter trial comparing detection of candidemia both from patients (including transplant recipients) with suspected candidemia as well as spiked samples, T2Candida achieved overall sensitivity and specificity of $91.1 \%$ and $99.4 \%$, as well as a significantly reduced turnaround time for the final assay result compared to conventional blood cultures [33]. Discordant results included two samples identified by blood culture that were missed by the T2Candida panel as well as 29 samples labeled positive by the T2Candida assay which were not identified by conventional methods. Some of these cases were later shown to represent Candida infections through other methods of detection. A subsequent study that included transplant recipients detected more episodes of candidemia as compared to conventional culture methods in patients on antifungals [34]. This system may have utility for early diagnosis, management, and antifungal stewardship in transplant populations at risk for Candida bloodstream infections, but prospective trials are needed to determine if rapid and enhanced diagnosis translates to reduced morbidity, mortality, or cost savings. The primary utility and cost savings of the T2MR platform may be related to antimicrobial stewardship.

Despite the significant theoretical advantages of the T2Candida assay, particularly in a transplant population with higher risk for candidemia, translating the reported diagnostic performance into real-world utility may be problematic for several reasons. First, though the initial validation study reported a sensitivity exceeding $90 \%$, the true sensitivity is likely to be lower as a majority of samples included in the study (44\%) were nonclinical, contrived specimens which contained a yeast concentration significantly higher than the mean concentration in initial blood cultures of candidemic patients (11-100 Candida CFU/mL vs. $1 \mathrm{CFU} / \mathrm{mL}$ ) [33]. Even a small decrease in sensitivity and therefore in negative predictive value reduces the utility of the assay in guiding initiation or continuation of antifungals in transplant patients with a high-pretest probability for candidemia, rendering such an assay much less useful diagnostically. Second, in its current iteration, T2Candida 
does not detect several clinically important Candida species (such as C. kefyr, C. lusitaniae, C. guilliermondii, and C. auris), which comprise up to $10 \%$ of Candida infections in SOT patients [35]. Finally, in both clinical trials and real-world settings, the T2Candida has been susceptible to a high frequency of technical errors as well as indeterminate or invalid readings that require repeat testing and are disruptive to workflow.

T2Candida auris is currently a research-use-only assay that detects the emerging and potentially MDR organism, Candida auris. A validation study investigating the ability to detect $C$. auris from cutaneous sites demonstrated a sensitivity of $89 \%$ and a specificity of $98 \%$ in comparison to CDC methods [36]. Given the propensity of $C$. auris to persist on environmental surfaces, to lead to hospital-based outbreaks, and potentially to donor-derived transplant infections, this assay has significant implications for hospital epidemiology of transplant patients [11,13].

The more recently FDA-approved assay for the T2MR system, T2Bacteria, can detect Enterococcus faecium, Staphylococcus aureus, Klebsiella pneumoniae, Acinetobacter baumannii, Pseudomonas aeruginosa, and Escherichia coli. No resistance information is provided. This assay was validated in a single-center study in comparison with conventional methods of bacterial identification from blood, achieving an overall sensitivity of $83.3 \%$ and specificity of $97.6 \%$. Notably, the sensitivity and specificity varied by the pathogen detected, ranging from $50 \%$ with K. pneumoniae to $100 \%$ with E. faecalis, P. aeruginosa, and S. aureus [37]. As with molecular methods applied to whole blood and blood culture, the T2Bacteria panel carries the potential to shorten time to diagnosis of BSI and may prove highly useful in transplant populations, but data will be needed to determine if theoretical advantages translate into real-world benefit.

\section{Metagenomic Sequencing}

Metagenomic next-generation sequencing is an unbiased, hypothesis-independent approach to pathogen detection that is directly applicable to clinical samples. In contrast with PCR-based and 16S ribosomal RNA gene-based sequencing which target specific primers, mNGS is capable of sequencing all the nucleic acids in a clinical specimen and entire pathogen genomes. The majority of mNGS-based assays sequence only DNA, excluding organisms with RNA genomes. To address this, complementary DNA can be synthesized from total RNA. In addition to pathogen identification, mNGS has the potential to identify genetic determinants associated with phenotypic resistance [38-40]. Due to its capacity to identifying a multitude of pathogens in clinical samples, careful interpretation of data and clinical correlation is needed. Current mNGS platforms may vary with regard to sequencing technologies and software packages required for data analyses [41]. Metagenomic methods have been applied to blood samples in transplant patients. A prospective study of allogeneic HSCT recipients evaluated the value of a commercially available mNGS assay on plasma (Karius, Karius Inc., Menlo Park, California) obtained prior to conditioning, at time of graft infusion, weekly intervals after transplant, and at 
time of acute illness [42]. Plasma mNGS added diagnostic value in 3 of 20 cases, including the identification of uncommon presentation of Chlamydia trachomatis and of MRSA infection prior to diagnosis by blood cultures. In addition to bacterial pathogens, plasma mNGS detected CMV and EBV in concordance with standard PCRs. In a multicenter blinded prospective study of 101 immunocompromised patients including 22 SOT and 18 HSCT, blood samples tested within 30 days of enrollment by an mNGS assay identified more clinically relevant viruses and bacteria than standard testing (36/101 vs. 11/101) [43]. In this study, mNGS was associated with a high negative predictive value compared with conventional diagnostics $(64 / 65,95 \%$ CI $0.95-1)$. These findings suggest that negative mNGS results may have a role in antimicrobial and diagnostic stewardship.

\section{Emerging Diagnostics for Respiratory Infections}

In the evaluation of community-acquired pneumonia, $40-60 \%$ of cases remain undiagnosed despite extensive testing with traditional microbiologic tests [44]. Sputum cultures and blood cultures provide diagnostic information in only $15 \%$ of cases of community-acquired pneumonia, while bronchoscopy provides additive diagnostic value in $50 \%$ of cases. The diagnostic yield of microscopy with staining of induced sputum for Pneumocystis jirovecii pneumonia is around 50\%, while that of serum galactomannan for Aspergillus infection can be as low as 30\%, depending on the population. Aspergillus PCR assays, gas chromatography-mass spectrometry of exhaled metabolites, multiplex PCR, and mNGS have the potential to significantly improve diagnostic sensitivity for respiratory pathogens,

\section{Aspergillus PCR}

\section{Aspergillus PCR for Diagnosis of Invasive Pulmonary Aspergillosis}

Invasive pulmonary aspergillosis (IPA) is the most common fungal infection among HSCT recipients and one of the most common among SOT patients, particularly lung transplant recipients. Conventional methods for diagnosis of IPA include histopathology demonstrating septated hyphae and growth on culture followed by species identification. However, the diagnosis of aspergillosis can sometimes be challenging using these methods alone. Indeed, barriers to biopsy, such as severe thrombocytopenia, are common in this population. Additionally, culture yield is variable, especially with antecedent antifungals, and histopathological findings cannot reliably distinguish Aspergillus species from other hyaline molds. Galactomannan antigen testing on serum and bronchoalveolar lavage (BAL) fluid serves as an additional diagnostic tool and an important adjunct for diagnosis, but the sensitivity is suboptimal and significantly impacted by treatment with triazoles.

Molecular testing with PCR on blood or respiratory specimens is an emerging method to diagnose IPA. Multiple genetic targets have been investigated, including $18 \mathrm{~s}$ rRNA, $18 \mathrm{~s}$ rDNA, 5.8S rDNA, $28 \mathrm{~s}$ rRNA, mitochondrial DNA, and internal 
Table 2 Commercially available PCR assays and platforms for Aspergillus species identification

\begin{tabular}{|c|c|c|c|c|c|}
\hline $\begin{array}{l}\text { Assay and } \\
\text { manufacturer }\end{array}$ & Methodology & Target & $\begin{array}{l}\text { Species } \\
\text { identified/ } \\
\text { readout }\end{array}$ & $\begin{array}{l}\text { Resistance } \\
\text { mutations } \\
\text { identified }\end{array}$ & $\begin{array}{l}\text { Tested specimens } \\
\text { and performance }\end{array}$ \\
\hline $\begin{array}{l}\text { AsperGenius } \\
\text { (PathoNostics) }\end{array}$ & $\begin{array}{l}\text { Real-time } \\
\text { multiplex } \\
\text { PCR kit }\end{array}$ & $\begin{array}{l}28 \text { s rDNA; } \\
\text { CYP51A }\end{array}$ & $\begin{array}{l}\text { A. fumigatus, } \\
\text { A. terreus, } \\
\text { Aspergillus spp. }\end{array}$ & $\begin{array}{l}\text { CYP51A } \\
\text { mutations: } \\
\text { 1) L98H } \\
\text { 2) Tandem } \\
\text { repeat } 34 \\
\text { 3) T289A } \\
\text { 4) Y121F }\end{array}$ & $\begin{array}{l}\text { BAL } \\
80.0-88.9 \% \\
\text { sensitive, } \\
84.0-93.3 \% \\
\text { specific per } \\
\text { patient } \\
\text { population; } \\
\text { compared against } \\
\text { BAL } \\
\text { galactomannan } \\
\text { and/or culture } \\
{[53,54]} \\
\text { Serum } \\
78.6 \% \text { sensitive, } \\
100 \% \text { specific for } \\
\text { serum samples of } \\
\text { patients with } \\
\text { proven/probable/ } \\
\text { possible disease } \\
{[55]} \\
\text { Plasma } \\
80 \% \text { sensitive, } \\
77.8 \% \text { specific } \\
\text { for plasma } \\
\text { samples of } \\
\text { patients with } \\
\text { proven/probable/ } \\
\text { possible disease } \\
{[56]}\end{array}$ \\
\hline $\begin{array}{l}\text { A. fumigatus } \\
\text { Bio-Evolution } \\
\text { (Bio-Evolution) }\end{array}$ & $\begin{array}{l}\text { Real time } \\
\text { PCR kit }\end{array}$ & ITS1 rDNA & A. fumigatus & None & $\begin{array}{l}\text { BAL } \\
100 \% \text { sensitive, } \\
81 \% \text { specific for } \\
\text { BAL samples of } \\
\text { patients with } \\
\text { probable/possible } \\
\text { disease [62] }\end{array}$ \\
\hline $\begin{array}{l}\text { MycoGENIE } \\
\text { (Ademtech) }\end{array}$ & $\begin{array}{l}\text { Real-time } \\
\text { multiplex } \\
\text { PCR kit }\end{array}$ & $\begin{array}{l}28 \text { s rRNA; } \\
\text { CYP51A }\end{array}$ & $\begin{array}{l}\text { A. fumigatus, } \\
\text { Aspergillus sp. }\end{array}$ & $\begin{array}{l}\text { CYP51A } \\
\text { mutations } \\
\text { 1) Tandem } \\
\text { repeat } 34 \\
\text { 2) L98H }\end{array}$ & $\begin{array}{l}\text { BAL } \\
100 \% \text { sensitive, } \\
71 \% \text { specific for } \\
\text { BAL samples of } \\
\text { patients with } \\
\text { probable/possible } \\
\text { disease [62] } \\
40 \% \text { sensitive, } \\
69 \% \text { specific for } \\
\text { BAL samples of } \\
\text { patients with } \\
\text { proven/probable } \\
\text { disease [58] }\end{array}$ \\
\hline
\end{tabular}


Table 2 (continued)

\begin{tabular}{|c|c|c|c|c|c|}
\hline $\begin{array}{l}\text { Assay and } \\
\text { manufacturer }\end{array}$ & Methodology & Target & $\begin{array}{l}\text { Species } \\
\text { identified/ } \\
\text { readout }\end{array}$ & $\begin{array}{l}\text { Resistance } \\
\text { mutations } \\
\text { identified }\end{array}$ & $\begin{array}{l}\text { Tested specimens } \\
\text { and performance }\end{array}$ \\
\hline & & & & & $\begin{array}{l}\text { Serum } \\
100 \% \text { sensitive, } \\
84.6 \% \text { specific } \\
\text { for serum } \\
\text { samples of } \\
\text { patients with } \\
\text { proven/probable } \\
\text { disease [57] }\end{array}$ \\
\hline $\begin{array}{l}\text { MycAssay } \\
\text { Aspergillus } \\
\text { (Myconostica/ } \\
\text { Lab21) }\end{array}$ & $\begin{array}{l}\text { Real-time } \\
\text { PCR kit }\end{array}$ & $18 \mathrm{~s}$ rRNA & Aspergillus spp. & None & $\begin{array}{l}\text { BAL } \\
86.7-93 \% \\
\text { sensitive, } \\
82.4-87.6 \% \\
\text { specific (range } \\
\text { dependent on } \\
\text { number of } \\
\text { samples tested) } \\
\text { for BAL samples } \\
\text { of patients with } \\
\text { probable disease } \\
\text { [99] } \\
60-70 \% \\
\text { sensitive, } \\
90.5-100 \% \\
\text { specific for BAL } \\
\text { samples of } \\
\text { patients with } \\
\text { proven/probable } \\
\text { disease [59] } \\
94.1 \% \text { sensitive, } \\
98.6 \% \text { specific } \\
\text { for BAL samples } \\
\text { of patients with } \\
\text { proven/probable } \\
\text { disease [61] } \\
\text { Serum } \\
43.8 \% \text { sensitive, } \\
63.2 \% \text { specific } \\
\text { for serum } \\
\text { samples of } \\
\text { patients with } \\
\text { proven/probable/ } \\
\text { possible disease } \\
\text { [60] } \\
65.4 \% \text { sensitive, } \\
57.8 \% \text { specific } \\
\text { for serum of } \\
\text { patients with } \\
\text { proven/probable } \\
\text { disease [100] } \\
\text { Biopsy }\end{array}$ \\
\hline
\end{tabular}


Table 2 (continued)

\begin{tabular}{|c|c|c|c|c|c|}
\hline $\begin{array}{l}\text { Assay and } \\
\text { manufacturer }\end{array}$ & Methodology & Target & $\begin{array}{l}\text { Species } \\
\text { identified/ } \\
\text { readout }\end{array}$ & $\begin{array}{l}\text { Resistance } \\
\text { mutations } \\
\text { identified }\end{array}$ & $\begin{array}{l}\text { Tested specimens } \\
\text { and performance }\end{array}$ \\
\hline & & & & & $\begin{array}{l}82-90 \% \\
\text { sensitive, } \\
64-79 \% \text { specific } \\
\text { for biopsy } \\
\text { specimens as } \\
\text { compared to } \\
\text { microscopy and } \\
\text { culture based } \\
\text { diagnosis [101] }\end{array}$ \\
\hline $\begin{array}{l}\text { PLEX-ID } \\
\text { Broad Fungal } \\
\text { (Abbott) }\end{array}$ & $\begin{array}{l}\text { PCR with } \\
\text { electrospray } \\
\text { ionization } \\
\text { mass } \\
\text { spectrometry; } \\
\text { PLEX-ID } \\
\text { platform }\end{array}$ & $\begin{array}{l}\text { mtSSU } \\
\text { rRNA, } \\
\text { proprietary } \\
\text { primers }\end{array}$ & $\begin{array}{l}\text { A. fumigatus, } \\
\text { A. flavus, } \\
\text { A. nidulans, } \\
\text { A. niger, } \\
\text { A. terreus } \\
\text { Other } \\
\text { non-Aspergillus } \\
\text { species detected } \\
\text { as well }\end{array}$ & None & $\begin{array}{l}\text { Respiratory } \\
\text { samples } \\
\text { Correctly } \\
\text { identified of } 11 \text { of } \\
12 \text { standard } \\
\text { samples and } 6 \text { of } \\
8 \text { samples from } \\
\text { respiratory } \\
\text { samples [102] } \\
\text { No studies } \\
\text { conducted to } \\
\text { evaluating } \\
\text { sensitivity and } \\
\text { specificity }\end{array}$ \\
\hline $\begin{array}{l}\text { RenDx } \\
\text { Fungiplex } \\
\text { (Renishaw) }\end{array}$ & $\begin{array}{l}\text { PCR with } \\
\text { surface } \\
\text { enhanced } \\
\text { resonance } \\
\text { Raman } \\
\text { scattering } \\
\text { spectroscopy }\end{array}$ & $\begin{array}{l}18 \text { s rRNA, } \\
28 \text { s rRNA }\end{array}$ & $\begin{array}{l}\text { A. fumigatus } \\
\text { A. terreus, } \\
\text { A. niger, } \\
\text { A. flavus } \\
\text { Other } \\
\text { non-Aspergillus } \\
\text { species detected } \\
\text { as well }\end{array}$ & None & $\begin{array}{l}\text { Serum/plasma } \\
81.3 \% \text { sensitive, } \\
87.5 \% \text { specific } \\
\text { for serum/plasma } \\
\text { specimens of } \\
\text { patients with } \\
\text { proven/probable/ } \\
\text { possible disease } \\
\text { [66] }\end{array}$ \\
\hline $\begin{array}{l}\text { SeptiFast } \\
\text { (Roche) }\end{array}$ & $\begin{array}{l}\text { Real-time } \\
\text { multiplex } \\
\text { PCR; Roche } \\
\text { LightCycler } \\
\text { platform }\end{array}$ & ITS rDNA & $\begin{array}{l}\text { A. fumigatus } \\
\text { Other } \\
\text { non-Aspergillus } \\
\text { species detected } \\
\text { as well }\end{array}$ & None & $\begin{array}{l}\text { No studies } \\
\text { conducted to } \\
\text { evaluating } \\
\text { sensitivity and } \\
\text { specificity for } \\
\text { detection of } \\
\text { A. fumigatus. } \\
\text { Variability is } \\
\text { reported between } \\
\text { detection } \\
\text { A. fumigatus with } \\
\text { SeptiFast and } \\
\text { comparative } \\
\text { assays }\end{array}$ \\
\hline
\end{tabular}

Abbreviations: $B A L$ bronchoalveolar lavage; $m t S S U$ rRNA mitochondrial short subunit ribosomal ribonucleic acid; ITS internal transcribed spacer; $P C R$ polymerase chain reaction; $r D N A$ ribosomal deoxyribonucleic acid; $r R N A$ ribosomal ribonucleic acid 
transcribed spacer (ITS) regions [45]. Use of PCR for routine diagnosis of IPA has not been uniformly accepted by society guidelines. Whereas guidelines proposed by the European Organization for Research and Treatment of Cancer/Invasive Fungal Infections Cooperative Group in collaboration with the National Institute for Allergy and Infectious Diseases Mycosis Study Group (EORTC/MSG) advocate against PCR-based diagnosis given the lack of standardized testing procedures, more recent ESCMID-ECMM-ERS guidelines indicate that PCR should be considered in conjunction with other diagnostic testing [46, 47]. The 2016 Infectious Disease Society of America (IDSA) guidelines caution against the routine use of PCR without utilizing other standardized methods of diagnosis, but committee members differed in opinions regarding the utility of this platform with one group favoring use of PCR in conjunction with other standard methods and the other group indicating that lack of standardization among heterogeneous PCR methods needed to be addressed prior to being implemented for routine use [48].

Indeed, the primary challenge facing acceptance of PCR for the identification of Aspergillus species genetic material is assay standardization, which allows for uniform test performance and interpretation across institutions and in clinical trials. A Cochrane review of PCR methods for diagnosing Aspergillus species infection from blood demonstrated a mean sensitivity and specificity of $80.5 \%$ and $78.5 \%$, respectively, when compared to EORTC/MSG recommendations for diagnosis as a reference standard [49]. Following publication of the initial EORTC/MSG guidelines, the European Aspergillus PCR Initiative (EAPCRI) was formed in an effort to progress toward increased standardization. Comparison of protocols from involved centers yielded specific recommendations for processing serum and whole blood samples $[50,51]$. Notably, the DNA extraction protocol was identified as the most significant component of standardization. Utilizing standardized protocols, the sensitivity and specificity of diagnosing invasive aspergillosis by PCR were found to be similar to that of Aspergillus galactomannan and beta-D-glucan assays at the time these assays were included in guideline recommendations [52]. Accordingly, future guidelines are likely to incorporate Aspergillus PCR as a routine tool for the diagnosis of invasive disease.

Though several reference laboratories in the United States offer Aspergillus PCR testing in the form of laboratory-developed tests (LDT), there are currently no FDAapproved assays. In recent years, several commercially available PCR assays for identification of Aspergillus species in blood or bronchoalveolar lavage have become available in Europe, including the MycAssay Aspergillus assay (Microgen Bioproducts Ltd., Cambridge, United Kingdom), the AsperGenius assay (PathoNostics, Maastricht, Netherlands), the MycoGENIE assay (Ademtech, Pessac, France), the SeptiFast assay (Roche Molecular System, Basel, Switzerland), and the RenDx Fungiplex assay (Renishaw Diagnostics Ltd., Glasgow, United Kingdom) (Table 2). These PCR assays incorporate internal standardization protocols validated by the manufacturer, allowing a degree of reproducibility across institutions. Many kits are validated on multiple real-time PCR-capable instruments, permitting a given laboratory to utilize the assay on existing devices. 
The AsperGenius assay, a real-time PCR targeting the 18S rDNA, detects $A$. fumigatus complex, A. terreus, and other Aspergillus species (A. flavus and A. niger). The assay was initially evaluated on BAL samples in comparison with positive galactomannan samples in patients with suspected invasive aspergillosis. The sensitivity and specificity ranged from $80 \%$ to $88.9 \%$ and $89.3 \%$ to $93.3 \%$, respectively, depending on the patient population studied, with a higher sensitivity in leukemic and HSCT patients [53]. A larger retrospective study involving five European hospitals evaluated the performance of the AsperGenius assay on BAL in comparison with galactomannan and culture data in patients primarily with hematologic malignancies and HSCT and found a sensitivity and specificity of $80 \%$ and $84 \%$, respectively [54]. This assay has also been applied to serum, suggesting broader potential application $[55,56]$.

The MycoGENIE assay (Ademtech, France) identifies presence of Aspergillus fumigatus by targeting $28 \mathrm{~s}$ rRNA in clinical samples. This assay was validated using culture-positive bronchoalveolar lavage samples with a sensitivity of $92.9 \%$ and a specificity of $90.1 \%$ [57]. However, the sensitivity on BAL was only $40 \%$ for proven or probable IPA in a retrospective study from a majority of patients status-post HSCT. An increase in sensitivity and specificity was observed when the assay was combined with galactomannan antigen testing [58].

The MycAssay (Myconostica, Lab21, Manchester, UK), an early commercial kit detecting 15 Aspergillus species, targets $18 \mathrm{~s}$ rRNA. Validation studies used samples from patients primarily with hematologic malignancies and compared the assay to galactomannan and institution-derived PCR testing. Initial evaluation using samples spiked with Aspergillus fumigatus and samples from patients with possible/probable IPA demonstrated similar performance to an institutionally developed PCR panel [59]. However, subsequent investigations found a lower sensitivity and specificity for diagnosis of invasive aspergillosis as compared to galactomannan antigen testing $[60,61]$. The MycoGENIE assay demonstrated similar performance to the $A$. fumigatus Bio-Evolution assay (Bio-Evolution, France) in a retrospective analysis using BAL samples [62].

The Roche SeptiFast assay is based on real-time multiplex PCR using the Roche LightCycler platform and is capable of detecting multiple bacterial and fungal pathogens, including $A$. fumigatus. This assay has been investigated against blood culture, individual laboratory-developed PCR assays, and galactomannan testing in patients with hematologic malignancy and neutropenic fever, some of whom were recipients of or being conditioned for $\operatorname{HSCT}[63,64]$. Positive results for $A$. fumigatus were reported in these studies, but positive results were rarer than for bacterial pathogens or Candida species, reflecting either lower prevalence or lower sensitivity for aspergillosis. Notably, this platform was also found to support the diagnosis of invasive aspergillosis in two patients with hepatic transplantation [65]. A primary limitation is the ability to only detect $A$. fumigatus, whereas patients with SOT or HSCT are at an increased risk for other Aspergillus species as well.

The RenDx Fungiplex assay (Renishaw, United Kingdom) utilizes PCR and surface-enhanced resonance Raman scattering spectroscopy to detect amplified DNA. The assay was developed to detect ten fungal organisms, including $A$. 
fumigatus and A.terreus, and demonstrated a sensitivity of $85.7 \%$ when detecting Aspergillus species from blood in a group of patients including recipients of HSCT [66].

In a review of published literature, the sensitivities and specificities of aforementioned Aspergillus PCR assays were overall comparable but consistently higher in BAL than in serum and likely lower sensitivity in non-hematologic patients as well as in those on antifungal treatment or prophylaxis [67]. Active investigation is ongoing to determine the feasibility of incorporating these and other developing platforms into the difficult process of diagnosing invasive aspergillosis. At present they do not represent stand-alone diagnostic methods, and results must be evaluated in the context of the clinical presentation and all other available data.

\section{Aspergillus PCR for Diagnosis of Resistance in Aspergillus Species}

The need for improved diagnostics is further highlighted by the increasing prevalence of azole-resistant Aspergillus species worldwide [68]. The first azole-resistant Aspergillus fumigatus clinical isolates were reported in the United States and the Netherlands in 1997 and 1998 [69, 70]. Since then, the prevalence of resistance has risen to $10-15 \%$ in some areas of Europe. At this time, resistance appears to be uncommon in the United States, with surveys of clinical isolates reporting a resistance prevalence of less than $1.8 \%[58,71]$. Mutations in the CYP51A (ERG11) gene encoding sterol demethylase are primarily responsible for resistance seen in clinical A. fumigatus isolates. Resistance develops in the setting of selective pressure from long-term and widespread azole use such as with environmental application of triazoles as fungicides in mass agriculture and less commonly with conditions favoring active reproduction in vivo such as with long-term treatment of patients with aspergilloma. Some CYP51A mutations are associated with minimal inhibitory concentrations (MIC) that exceed the epidemiologic cutoff value (ECV) of $\leq 1 \mu \mathrm{g} /$ $\mathrm{mL}$ for azoles established by the Clinical \& Laboratory Standards Institute (CLSI) and the European Committee on Antimicrobial Susceptibility Testing (EUCAST) by multiple dilutions. The presence of such mutations has been linked to treatment failure and increased mortality in patients with IPA [15].

Among the aforementioned Aspergillus PCR assays, the AsperGenius and the MycoGENIE assays have the added capability of detecting azole resistance based on the presence of CYP51A mutations. The MycoGENIE assay detects two resistanceassociated mutations in CYP51A, whereas the AsperGenius assay identifies four CYP51A point mutations representing prevalent mutation types. In a retrospective study, samples with positive results for resistance-associated mutations using this assay were associated with significantly poorer patient outcomes [54].

Given the low prevalence of azole-resistant Aspergillus isolates in the United States, current IDSA guidelines do not recommend routine susceptibility testing. Susceptibility testing was suggested in cases of suspected azole resistance (without further specifications on when to suspect), lack of response to normally effective antifungals, or for epidemiologic purposes. With ongoing widespread clinical and 
industry use of triazoles in the United States, the prevalence of azole resistance is likely to increase, leading to a greater need for resistance detection.

\section{Gas Chromatography-Mass Spectrometry of Exhaled Metabolites}

Molds produce organic compounds during routine metabolism, many of which are released as volatile metabolites during exhalation. Monoterpenes and sesquiterpenes, the primary metabolites produced by Aspergillus species, can be detected using breath-based diagnostics to establish a diagnosis of invasive aspergillosis. The first report of this method involved recipients of SOT and HSCT with proven or suspected IPA [72]. The study compared volatile organic compounds produced in vitro with those detected from patient breath samples using gas chromatographymass spectrometry. Sesquiterpene compounds were detected from varying in vitro culture conditions as well as in breath samples. Breath-based detection of volatile organic compounds achieved a sensitivity of $94 \%$ and specificity of $93 \%$ for identifying patients with IPA as compared to clinical diagnosis by EORTC/MSG criteria. Some sesquiterpene metabolites were only identified in the in vivo breath samples corresponding to activation of alternate metabolic pathways in the context of an immune response and lung microbiome [73]. Notably, sesquiterpenes are produced in a species-specific manner by Aspergillus species, potentially allowing diagnostic discrimination beyond the genus level. Development of this method for clinical diagnosis has many challenges involving consistent breath collection, which can be affected by multiple factors including age, race, respiratory rate, and tidal volumes among others, and standardization of analysis methods used to identify the volatile organic compounds [73]. However, this platform has the potential to significantly improve the diagnostic yield for IPA and could be expanded to other invasive fungal infections, particularly those due to Mucorales species for which few targeted diagnostics are available.

\section{Multiplex PCR}

Respiratory multiplex PCR can be performed on nasopharyngeal swab samples, nasal washes/aspirates, and BAL specimens. There are currently five FDA-approved respiratory multiplex assays, including NxTAG Respiratory Pathogen Panel (RPP) (Luminex, TX, USA), Verigene Respiratory (RP) Flex (Nanosphere, IL, USA), FilmArray Respiratory Panel (RP) (BioFire Diagnostics, UT, USA), eSensor Respiratory Viral Panel (RVP) (Genmark, CA, USA), and, the recently approved, Unyvero Lower Respiratory (Curetis, CA, USA) (Table 3). The former four panels include predominantly viral targets, while Unyvero also detects bacterial pathogens and genes associated with antimicrobial resistance (Table 4) [74]. Such assays have the advantage of providing earlier diagnoses than culture- or immunofluorescence-based methods, as well as the potential to detect multiple coinfecting pathogens with early institution of appropriate therapy and enforcement of isolation practices, measures 
Table 3 Respiratory multiplex PCR assays

\begin{tabular}{|c|c|c|c|c|c|}
\hline & $\begin{array}{l}\text { FilmArray } \\
\text { RP }\end{array}$ & $\begin{array}{l}\text { NxTAG } \\
\text { RPP }\end{array}$ & $\begin{array}{l}\text { Verigene } \\
\text { RP Flex }\end{array}$ & $\begin{array}{l}\text { eSensor } \\
\text { RVP }\end{array}$ & $\begin{array}{l}\text { Unyvero lower } \\
\text { respiratory }\end{array}$ \\
\hline \multicolumn{6}{|l|}{ Viruses } \\
\hline Adenovirus (ADV) & $\mathrm{X}$ & $\mathrm{X}$ & $\mathrm{X}$ & $\begin{array}{l}\mathrm{X}(\mathrm{ADV} \\
\mathrm{B} / \mathrm{E} / \mathrm{C})\end{array}$ & \\
\hline Coronavirus HKU1 & $X$ & $\mathrm{X}$ & & & \\
\hline Coronavirus 229E & $\mathrm{X}$ & $\mathrm{X}$ & & & \\
\hline Coronavirus OC43 & $\mathrm{X}$ & $\mathrm{X}$ & & & \\
\hline Coronavirus NL63 & $\mathrm{X}$ & $\mathrm{X}$ & & & \\
\hline $\begin{array}{l}\text { Human } \\
\text { metapneumovirus }\end{array}$ & $\mathrm{X}$ & $\mathrm{X}$ & $\mathrm{X}$ & $\mathrm{X}$ & \\
\hline $\begin{array}{l}\text { Human rhinovirus/ } \\
\text { enterovirus }\end{array}$ & $\mathrm{X}$ & $\mathrm{X}$ & $\mathrm{X}$ & $\mathrm{X}$ & \\
\hline Influenza A & $X$ & $\mathrm{X}$ & $X$ & $\mathrm{X}$ & \\
\hline Influenza A/H1 & $\mathrm{X}$ & $\mathrm{X}$ & $\mathrm{X}$ & $\mathrm{X}$ & \\
\hline Influenza A/H3 & $\mathrm{X}$ & $\mathrm{X}$ & $\mathrm{X}$ & $\mathrm{X}$ & \\
\hline Influenza A/H1-2009 & $\mathrm{X}$ & & & $\mathrm{X}$ & \\
\hline Influenza B & $\mathrm{X}$ & $\mathrm{X}$ & $\mathrm{X}$ & $\mathrm{X}$ & \\
\hline $\begin{array}{l}\text { Parainfluenza viruses } \\
1,2,3,4\end{array}$ & $\mathrm{X}$ & $\mathrm{X}$ & $\mathrm{X}$ & $\mathrm{X}$ & \\
\hline $\begin{array}{l}\text { Respiratory syncytial } \\
\text { virus }\end{array}$ & $\mathrm{X}$ & $\begin{array}{l}\mathrm{X}(\mathrm{RSV} \\
\mathrm{A} / \mathrm{B})\end{array}$ & $\begin{array}{l}\text { X (RSVA/ } \\
\text { B) }\end{array}$ & $\begin{array}{l}\text { X (RSV } \\
\text { A/B) }\end{array}$ & \\
\hline Bocavirus & & $\mathrm{X}$ & & & \\
\hline \multicolumn{6}{|l|}{$\begin{array}{l}\text { Gram-positive } \\
\text { bacteria }\end{array}$} \\
\hline $\begin{array}{l}\text { Staphylococcus } \\
\text { aureus }\end{array}$ & & & & & $\mathrm{X}$ \\
\hline $\begin{array}{l}\text { Streptococcus } \\
\text { pneumoniae }\end{array}$ & & & & & $\mathrm{X}$ \\
\hline \multicolumn{6}{|l|}{ Enterobacteriaceae } \\
\hline Citrobacter freundii & & & & & $\mathrm{X}$ \\
\hline Escherichia coli & & & & & $\mathrm{X}$ \\
\hline $\begin{array}{l}\text { Enterobacter cloacae } \\
\text { complex }\end{array}$ & & & & & $\mathrm{X}$ \\
\hline $\begin{array}{l}\text { Enterobacter } \\
\text { aerogenes }\end{array}$ & & & & & $\mathrm{X}$ \\
\hline Proteus spp. & & & & & $X$ \\
\hline Klebsiella oxytoca & & & & & $X$ \\
\hline Klebsiella variicola & & & & & $X$ \\
\hline Serratia marcescens & & & & & $\mathrm{X}$ \\
\hline Morganella morganii & & & & & $\mathrm{X}$ \\
\hline \multicolumn{6}{|l|}{$\begin{array}{l}\text { Non-fermenting } \\
\text { bacteria }\end{array}$} \\
\hline $\begin{array}{l}\text { Moraxella } \\
\text { catarrhalis }\end{array}$ & & & & & $\mathrm{X}$ \\
\hline
\end{tabular}


Table 3 (continued)

\begin{tabular}{l|l|l|l|l|l}
\hline & $\begin{array}{l}\text { FilmArray } \\
\text { RP }\end{array}$ & $\begin{array}{l}\text { NxTAG } \\
\text { RPP }\end{array}$ & $\begin{array}{l}\text { Verigene } \\
\text { RP Flex }\end{array}$ & $\begin{array}{l}\text { eSensor } \\
\text { RVP }\end{array}$ & $\begin{array}{l}\text { Unyvero lower } \\
\text { respiratory }\end{array}$ \\
\hline $\begin{array}{l}\text { Pseudomonas } \\
\text { aeruginosa }\end{array}$ & & & & $\mathrm{X}$ \\
\hline $\begin{array}{l}\text { Acinetobacter } \\
\text { baumannii complex }\end{array}$ & & & & $\mathrm{X}$ \\
\hline $\begin{array}{l}\text { Stenotrophomonas } \\
\text { maltophilia }\end{array}$ & & & & $\mathrm{X}$ \\
\hline $\begin{array}{l}\text { Legionella } \\
\text { pneumophila }\end{array}$ & & $\mathrm{X}$ & & $\mathrm{X}$ \\
\hline $\begin{array}{l}\text { Others/fungi } \\
\text { Pnlamydophila }\end{array}$ & $\mathrm{X}$ & $\mathrm{X}$ & & $\mathrm{X}$ \\
\hline $\begin{array}{l}\text { Mycoplasma } \\
\text { pneumoniae }\end{array}$ & & & & $\mathrm{X}$ \\
\hline $\begin{array}{l}\text { Haemophilus } \\
\text { influenzae }\end{array}$ & & $\mathrm{X}$ & $\mathrm{X}$ & $\mathrm{X}$ \\
\hline $\begin{array}{l}\text { Pneumocystis } \\
\text { jirovecii }\end{array}$ & & & & $\mathrm{X}$ \\
\hline $\begin{array}{l}\text { Bordetella } \\
\text { parapertussis }\end{array}$ & $\mathrm{X}$ & & & \\
\hline $\begin{array}{l}\text { Bordetella pertussis } \\
\text { Bordetella holmesii }\end{array}$ & & & & \\
\hline
\end{tabular}

Table 4 Unyvero resistance gene panel

\begin{tabular}{l|l}
\hline Resistance & Gene \\
\hline Carbapenem & KPC \\
\cline { 2 - 2 } & NDM \\
\hline & OXA-23 \\
\cline { 2 - 2 } & OXA-24 \\
\hline & OXA-48 \\
\hline Third-generation cephalosporins & OXA-58 \\
\hline Oxacillin/cefoxitin & VIM \\
\hline Penicillin & CTX-M \\
\hline & mecA \\
\hline & TEM \\
\hline
\end{tabular}

that are especially critical for the care of immunocompromised hosts. However, studies of these assays among immunocompromised patients are limited. The FilmArray RP was evaluated in 87 immunocompromised patients (48\% HSCT, $37 \%$ SOT and $18 \%$ with hematologic malignancies) using either BAL or nasopharyngeal samples [75]. In this cohort, only viral pathogens were detected. The positive and negative predictive values were $86 \%$ and $100 \%$, respectively. Unyvero was evaluated in BAL samples of 522 immunocompromised patients with suspected 
lower respiratory tract infections [76]. Compared to conventional methods, the assay result was more expedient (available within 5 hours), but sensitivity was poor at $68.4 \%$ (specificity was $86 \%$ ), notably failing to identify cases of Streptococcus pneumoniae infection.

\section{Metagenomic Sequencing}

In patients without a microbiologic diagnosis using conventional testing, mNGS may have a role in providing an early and definitive diagnosis, which is especially important in lung transplant recipients for whom respiratory infection is associated with allograft dysfunction and mortality. Using a laboratory-developed mNGS assay in a cohort of lung transplant recipients with suspected respiratory infection, Lewdowonska et al. [77] identified respiratory viral pathogens in only 5 of 29 cases (Table 5). Langelier et al. [78] enrolled 22 HSCT recipients with respiratory illness whose BAL was tested by standard microbiologic testing and mNGS. Standard microbiologic testing identified clinically relevant pathogens (as

Table 5 Utility of metagenomic next-generation sequencing (mNGS) on respiratory specimens for diagnosis of pneumonia in SOT and HSCT recipients

\begin{tabular}{|c|c|c|c|c|c|}
\hline Source & $\begin{array}{l}\text { No of } \\
\text { cases }\end{array}$ & Transplant & $\begin{array}{l}\text { Clinical } \\
\text { presentation }\end{array}$ & $\begin{array}{l}\text { Clinical } \\
\text { specimen }\end{array}$ & Pathogen(s) \\
\hline $\begin{array}{l}\text { Lewandowska } \\
\text { et al. [77] }\end{array}$ & 29 & $\begin{array}{l}\text { Lung } \\
\text { transplant }\end{array}$ & $\begin{array}{l}\text { Respiratory } \\
\text { illness }\end{array}$ & $\begin{array}{l}\text { Throat } \\
\text { swab } \\
(27) \\
\text { BAL (2) }\end{array}$ & $\begin{array}{l}\text { Respiratory pathogens } \\
\text { Rhinovirus A and B (4/ } \\
29) \\
\text { Human coronavirus (1/ } \\
29) \\
\text { Non-respiratory } \\
\text { pathogens } \\
\text { Human herpes virus-7 } \\
(18 / 29) \\
\text { Torque teno virus (9/ } \\
29)\end{array}$ \\
\hline $\begin{array}{l}\text { Langelier et } \\
\text { al. [78] }\end{array}$ & 22 & HSCT & $\begin{array}{l}\text { Acute } \\
\text { respiratory } \\
\text { illness }\end{array}$ & BAL & $\begin{array}{l}6 / 22 \text { cases identified by } \\
\text { conventional and } \\
\text { mNGS } \\
6 / 22 \text { cases were novel } \\
\text { pathogens identified by } \\
\text { mNGS } \\
10 / 22 \text { cases identified } \\
\text { by mNGS of uncertain } \\
\text { or unlikely } \\
\text { pathogenicity }\end{array}$ \\
\hline Li et al. [79] & 5 & $\begin{array}{l}\text { Allogeneic } \\
\text { HSCT }\end{array}$ & $\begin{array}{l}\text { Lower } \\
\text { respiratory } \\
\text { infection }\end{array}$ & $\begin{array}{l}\text { Lung } \\
\text { tissue }\end{array}$ & $\begin{array}{l}\text { Fungal infection } \\
\text { diagnosed in } 5 / 5 \text { with } \\
\text { mNGS }\end{array}$ \\
\hline
\end{tabular}

$B A L$ bronchoalveolar lavage; HSCT hematopoietic stem cell transplantation; SOT solid organ transplantation 
determined by the treating physician) in six cases, all of which were concordant with mNGS. Conversely, six other cases identified by mNGS were missed by conventional testing. Studies of mNGS for the diagnosis of fungal infections in transplant recipients are limited. Li et al. evaluated 20 patients by lung biopsy, 5 of which were allogeneic HSCT recipients [79]. Histopathology demonstrated fungal elements in 5/ 5 , while fungal culture was only positive in $2 / 5$. mNGS identified fungal species as follows: Rhizopus microsporus (2), Mucor racemosus (2), and Rhizopus oryzae (1). Although available studies are small and require validation in larger cohort, they emphasize the diagnostic potential of mNGS in comparison with standard diagnostics. In addition to pathogen identification, one study stressed the potential role of mNGS in the identification of genetic determinants related to host immune response of immunocompromised patients with confirmed lower respiratory infection [78]. Explify $^{\text {TM }}$ Respiratory (IDbyDNA, San Francisco, USA) is a commercially available mNGS assay validated for BAL and detects hundreds of bacterial, fungal, and viral respiratory pathogens in a single run with result turnaround time of $2-3$ days. In a study among immunocompromised children with suspected pneumonia $(42 \%$ of which had underlying hematologic malignancies), mNGS testing demonstrated high agreement with conventional microbiologic tests $(90.2 \%$ for bacterial, $94.1 \%$ for virus, $66.7 \%$ for fungal detection). The assay also identified putative and possible infectious causes in $44 \%$ of children with suspected respiratory infections whose conventional testing was negative [80].

\section{Emerging Diagnostics for CNS Infections}

Identification of the causative agent of encephalitis and differentiation between infectious and noninfectious processes are critical in delineating the treatment approach for transplant recipients and potential deceased donors with encephalitis/ meningitis syndromes. The conventional diagnostic approach to encephalitis consists of testing tailored to a patient's clinical presentation and epidemiologic exposures including targeted antigen-based, PCR, and serologic assays. Despite extensive concurrent and sequential testing, the underlying pathogen remains unclear in up to $60 \%$ of encephalitis cases [81]. Novel diagnostics for CNS infections, on the other hand, have the capacity to test for dozens or even hundreds of pathogens simultaneously. These include targeted multiplexed PCR assays and mNGS.

\section{Multiplex PCR}

Multiplex PCR assays that include several viral, bacterial, and fungal targets are now available. The FilmArray meningitis/encephalitis (ME) panel (Biofire Diagnostics) tests for six bacterial (E. coli K1, H. influenzae, L. monocytogenes, $N$. meningitides, S. pneumoniae, S. agalactiae), seven viral (HSV1-2, VZV, CMV, HHV6, Enterovirus, human parechovirus), and two fungal pathogens (C. neoformans and C. gattii) 
on cerebrospinal fluid (CSF) with a turnaround time of $1 \mathrm{~h}$. In a multicenter study of 1560 prospectively collected CSF samples utilizing FilmArray ME panel versus conventional techniques (i.e., culture for bacteria and monoplex PCR for other agents [82 ], the FilmArray ME panel had a sensitivity of $100 \%$ for $9 / 14$ pathogens (E. coli K1, H. influenzae, S. pneumoniae, CMV, HSV-1, HSV-2, human parechovirus, VZV, Cryptococcus neoformans/gattii). Enterovirus and HHV-6 had an agreement of $95.7 \%$ and $85.7 \%$, respectively. The specificity was $\geq 99.2 \%$ for all 14 pathogens. This study did not include immunocompromised hosts, but other studies include limited data for this population. Chang et al. evaluated the ME panel in hospitalized patients, which included eight immunocompromised patients (HIV/ AIDS, steroid use, active chemotherapy, transplant). The ME panel detected HHV-6 in an HSCT recipient with symptoms of encephalitis, while the concurrent HHV-6 PCR was negative [83]. There are emerging data that the sensitivity of ME panel for Cryptococcus is relatively poor compared to conventional testing. The ME panel failed to detect Cryptococcus in CSF twice, resulting in delayed diagnosis in a kidney transplant recipient [84]. The diagnosis was later confirmed by the conventional cryptococcal antigen lateral flow assay. Another study retrospectively evaluated patients who underwent CSF or serum testing for Cryptococcus with ME panel CSF culture and antigen testing [85]. Twelve of the 14 cases who met inclusion criteria were HIV-positive. Of the 14 cases with positive CSF cryptococcal antigens, 5 had positive ME and culture. Among the nine cases with negative ME, two had positive culture, and seven had negative culture. The sensitivity was calculated at $71.4 \%$ while specificity was $100 \%$. Based on these two reports, a negative ME result for Cryptococcus does not rule out cryptococcal meningitis, especially in at-risk patients.

\section{Metagenomic Sequencing}

mNGS carries the potential for hypothesis-independent testing of hundreds of pathogens simultaneously and may be particularly useful when applied to normally sterile specimens such as CSF. The value of mNGS in the diagnosis of encephalitis in SOT and HSCT recipients has already been demonstrated (Table 6). In a review of the current literature, 8 of 17 cases diagnosed with mNGS involved novel pathogens including arenavirus [3/17], astrovirus [4/17], and human betacoronavirus [1/17]. Unexpected etiologies such as Candida and Hepatitis E encephalitis were found in two cases. Donor-derived transmission of tick-borne virus encephalitis [86] and possibly due to arenavirus [87] was also reported. These cases illustrate the potential use of mNGS in diagnosing meningoencephalitis of unclear etiology in potential organ donors, a high-risk category that normally precludes utilization of organs due to concern for transmission of life-threatening infectious pathogens not detected by conventional testing. 


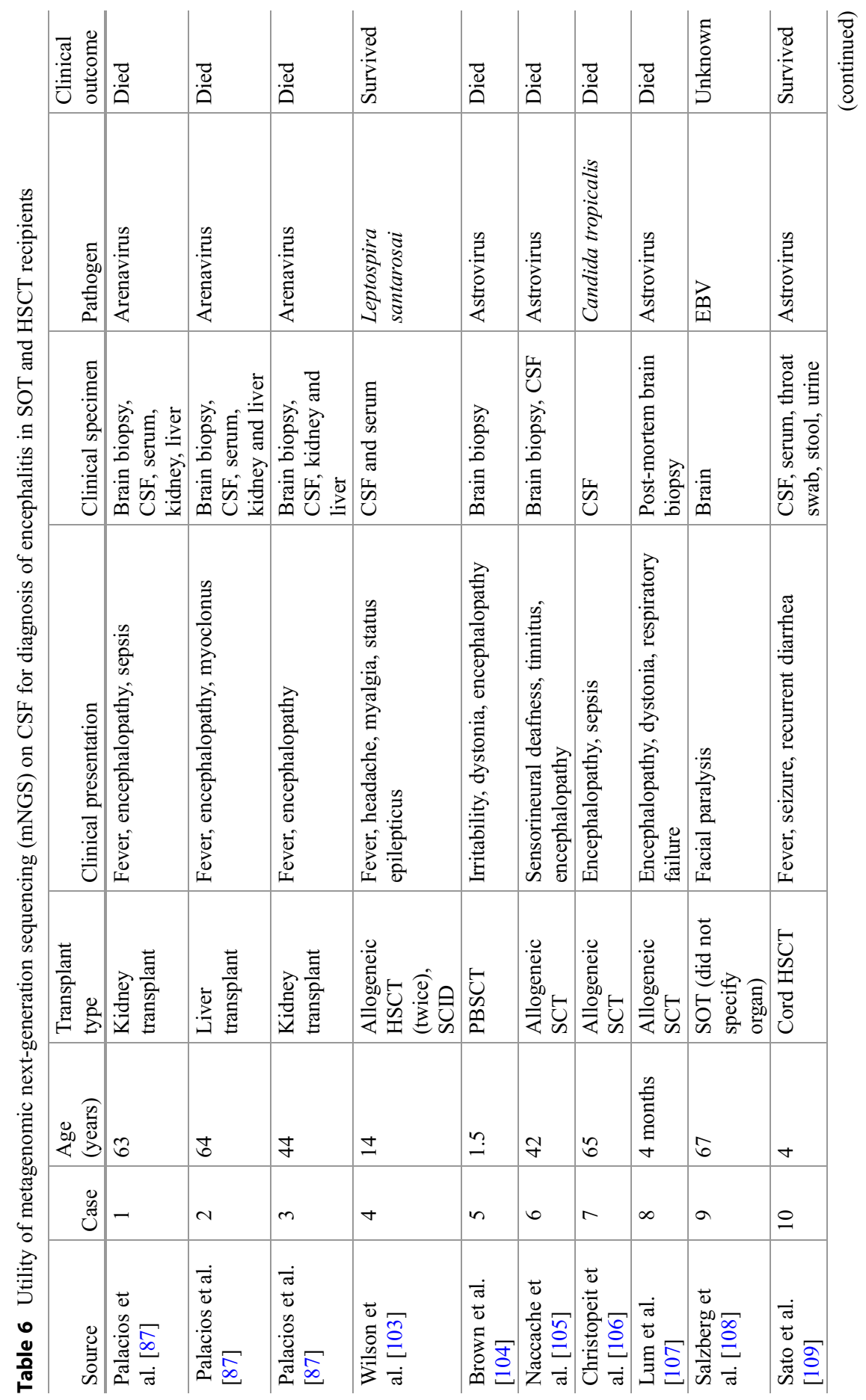




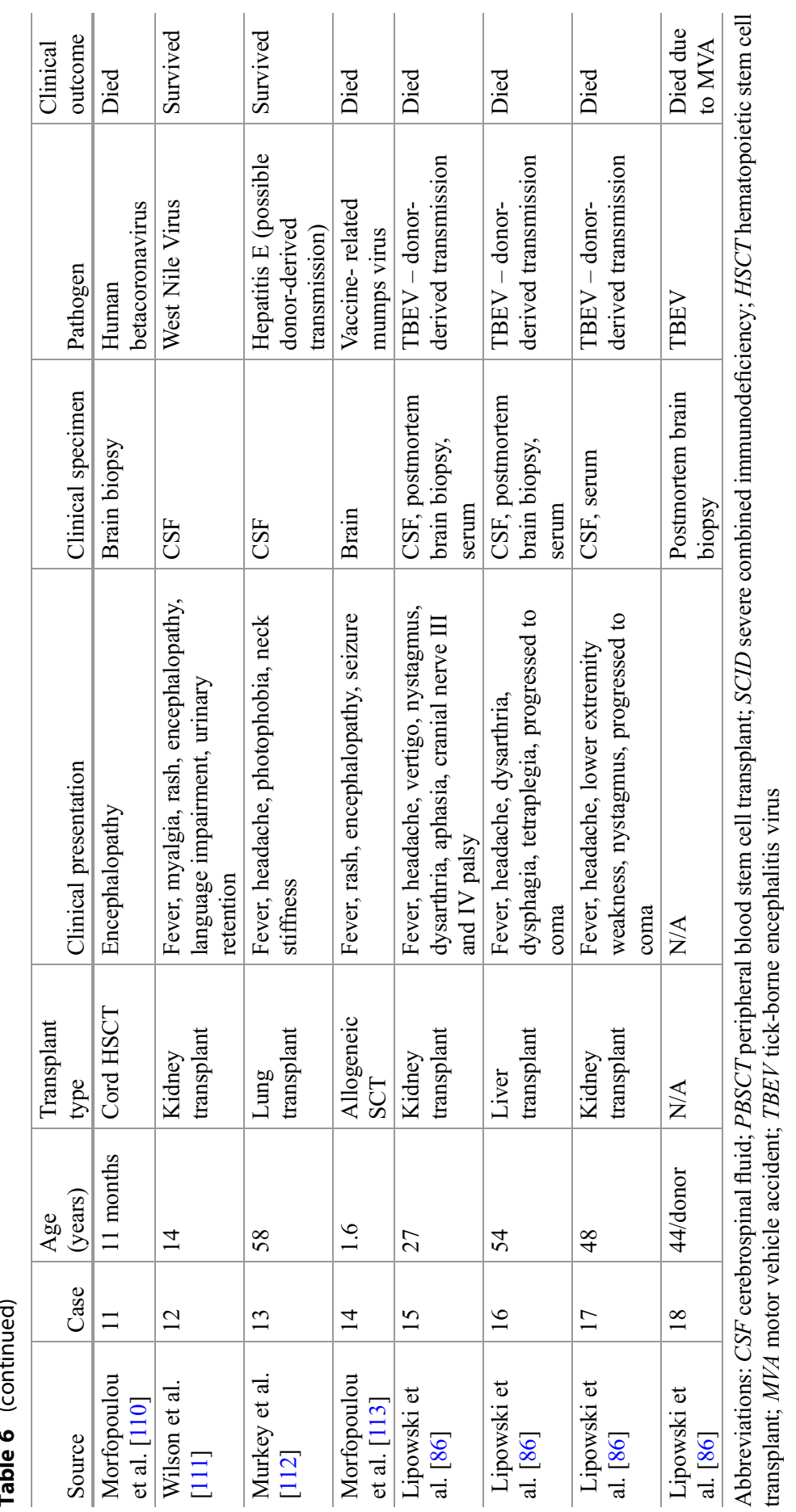




\section{Emerging Diagnostics for Gastrointestinal Infections}

Diarrheal disease is associated with significant morbidity and mortality for immunocompromised hosts. In SOT recipients, diarrhea is associated with poorer graft survival and increased risk for death [88]. Establishing a diagnosis early and accurately allows providers to distinguish infectious from noninfectious causes including immunosuppressive drug-related (e.g., mycophenolate) or graft-versushost disease-related diarrhea, which require special intervention. In comparison with conventional testing, which includes stool culture, microscopy, and antigen testing, molecular assays can identify multiple pathogens simultaneously with shorter turnaround times.

\section{Multiplex PCR}

There are currently three FDA-approved multiplex tests for gastrointestinal pathogens: FilmArray Gastrointestinal Panel (Biofire Diagnostics, Utah, USA), xTag Gastrointestinal Pathogens Panel (GPP) (Luminex, Texas, USA), and Verigene Enteric Pathogens (Nanosphere, Illinois, USA) (Table 7). Studies in immunocompromised patients with gastrointestinal illness are limited. Mengelle et al. evaluated xTag GPP in 102 adult organ transplant recipients with diarrhea [89]. Twenty-five of 147 samples $(17 \%)$ collected were positive for at least one pathogen. Toxigenic $C$. difficile, norovirus, and Salmonella spp. were detected in 7.5\%, 4.1\%, and 2.7\%, respectively. Coste et al. evaluated xTAG GPP in 49 adult kidney transplant recipients with 54 severe diarrhea events [90]. Among 39 positive samples, multiplex PCR identified multiple infections in 15 (38\%), providing additional diagnoses compared to traditional tests. The most common pathogens identified by multiple PCR were enteropathogenic E. coli (15/39, 38\%), Campylobacter spp. (15/39, 38\%), and norovirus $(14 / 39,36 \%)$. Despite the potential for additional diagnoses, there are drawbacks to increased sensitivity. Since nucleic acids of viable and nonviable pathogens including free DNA/RNA is not distinguished [91], disease, asymptomatic carriage, or shedding (particularly with certain viruses) can be confounded. This includes detection of $C$. difficile [92-94] which may represent colonization rather than infection. Detection of more than one pathogen [95], though sometimes useful, may render result interpretation difficult. As opposed to culture techniques, multiplex PCR assays do not provide antimicrobial susceptibility, information that is essential for antimicrobial stewardship and epidemiologic monitoring. Notably, GI panels that include adenovirus such as GPP and FilmArray assays only target adenovirus types F40/41. However, other adenovirus types especially within subgroup $\mathrm{C}$ cause most infections among transplant patients, so these assays do not rule out adenovirus gastroenteritis [96]. 
Table 7 Gastrointestinal multiplex PCR assays

\begin{tabular}{|c|c|c|c|}
\hline & FilmArray GI & $x T A G G P P$ & Verigene EP \\
\hline \multicolumn{4}{|l|}{ Virus } \\
\hline Adenovirus $40 / 41$ & $\mathrm{X}$ & $\mathrm{X}$ & $\mathrm{X}$ \\
\hline Norovirus genogroups I and II & $\mathrm{X}$ & $\mathrm{X}$ & $\mathrm{X}$ \\
\hline Rotavirus A & $\mathrm{X}$ & $\mathrm{X}$ & $\mathrm{X}$ \\
\hline Sapovirus & $\mathrm{X}$ & & \\
\hline Astrovirus & $\mathrm{X}$ & & \\
\hline \multicolumn{4}{|l|}{ Bacteria } \\
\hline Campylobacter & $\mathrm{X}$ & $\mathrm{X}$ & \\
\hline Clostridiodes difficile (toxin $A / B$ ) & $\mathrm{X}$ & $\mathrm{X}$ & \\
\hline Plesiomonas shigelloides & $\mathrm{X}$ & & \\
\hline Salmonella & $\mathrm{X}$ & $\mathrm{X}$ & $\mathrm{X}$ \\
\hline Yersinia enterocolitica & $\mathrm{X}$ & & $\mathrm{X}$ \\
\hline Vibrio spp. & $\mathrm{X}$ & $\mathrm{X}$ & $\mathrm{X}$ \\
\hline Enteroaggregative $E$. coli & $\mathrm{X}$ & & \\
\hline Enteropathogenic E. coli & $\mathrm{X}$ & & \\
\hline Enterotoxigenic $E$. coli & $\mathrm{X}$ & $\mathrm{X}$ & \\
\hline Shiga-like toxin producing $E$. coli & $\mathrm{X}$ & $\mathrm{X}$ & $\mathrm{X}$ \\
\hline E. coli 0157 & $\mathrm{X}$ & $\mathrm{X}$ & \\
\hline Enteroinvasive $E$. coli/Shigella & & $\mathrm{X}$ & $\mathrm{X}$ \\
\hline \multicolumn{4}{|l|}{ Parasite } \\
\hline Cryptosporidium & $\mathrm{X}$ & $\mathrm{X}$ & \\
\hline Cyclospora cayetanensis & $\mathrm{X}$ & & \\
\hline Entamoeba histolytica & $X$ & $X$ & \\
\hline Giardia lamblia & $\mathrm{X}$ & $\mathrm{X}$ & \\
\hline
\end{tabular}

\section{Conclusion}

In the past decade, several novel diagnostic modalities have emerged with the potential to revolutionize the diagnosis of infectious diseases in transplant patients in a way comparable to the effect of MALDI-TOF MS on general microbiological diagnostics. Though significant strides have been made, most modalities continue to have certain drawbacks that limit their applicability. Molecular methods applicable directly to blood samples for the diagnosis of BSI benefit from very short processing times but suffer from lower sensitivity due to circumvention of a growth phase, while assays performed on positive blood cultures are generally more sensitive except for fastidious or unculturable organisms. T2 magnetic resonance-based testing is rapid and highly sensitive, but translating the reported diagnostic performance into realworld utility has been problematic. mNGS has significant potential for rapid and broad detection of pathogens in multiple specimen types, but current methods remain less sensitive than targeted PCR tests that are based on amplification [97], and cost of commercial mNGS assays is prohibitive. Breath-based diagnosis has 
been shown to improve the diagnosis of invasive aspergillosis, yet there remain important challenges to its application. Despite their shortcomings, emerging technologies have already demonstrated a diagnostic advantage as well as a positive impact on patient outcomes [98]. Though data on test performance characteristics and clinical impact among transplant patients remains limited, it is likely that these modalities will translate into even greater utility given the increased risk for infection and propensity for multiple and uncommon pathogens in this population.

\section{Key Points}

- Transplant patients are at increased risk for community-acquired and opportunistic pathogens, multiple pathogens simultaneously, and multidrug-resistant organisms.

- Diagnostic microbiology has witnessed a shift toward culture-independent methods in the past decade.

- Molecular methods applicable directly to blood samples for the diagnosis of BSI benefit from very short processing times but suffer from lower sensitivity due to circumvention of a growth phase.

- Molecular assays performed on positive blood cultures are more sensitive except for fastidious or unculturable organisms.

- T2 magnetic resonance-based testing is rapid and highly sensitive, but translating the reported diagnostic performance into real-world utility has been problematic.

- Metagenomic next-generation sequencing has massive potential for rapid and broad detection of pathogens in multiple specimen types, but current methods remain less sensitive than targeted PCR tests.

- Breath-based diagnosis has been shown to improve the diagnosis of invasive aspergillosis, yet there remain important challenges to its application.

- Despite shortcomings, emerging technologies have already demonstrated a diagnostic advantage as a well as a positive impact on patient outcomes.

- Though data on test performance characteristics and clinical impact among transplant patients remains scarce, it is likely that these modalities will translate into even greater utility in this population.

\section{References}

1. Fair RJ, Tor Y. Antibiotics and bacterial resistance in the 21 st century. Perspect Medicin Chem. 2014;6:25-64.

2. Kumar A, Roberts D, Wood KE, Light B, Parrillo JE, Sharma S, et al. Duration of hypotension before initiation of effective antimicrobial therapy is the critical determinant of survival in human septic shock. Crit Care Med. 2006;34(6):1589-96.

3. Viehman JA, Clancy CJ, Clarke L, Shields RK, Silveira FP, Kwak EJ, et al. Surgical site infections after liver transplantation: emergence of multidrug-resistant Bacteria and implications for prophylaxis and treatment strategies. Transplantation. 2016;100(10):2107-14. 
4. Camargo JF. Donor-derived infections in solid organ transplant recipients: challenging the 30day paradigm. Transpl Infect Dis. 2017;19(2):e12836.

5. Lanini S, Costa AN, Puro V, Procaccio F, Grossi PA, Vespasiano F, et al. Incidence of carbapenem-resistant gram negatives in Italian transplant recipients: a nationwide surveillance study. PLoS One. 2015;10(4):e0123706.

6. Averbuch D, Tridello G, Hoek J, Mikulska M, Akan H, Yanez San Segundo L, et al. Antimicrobial resistance in gram-negative rods causing bacteremia in hematopoietic stem cell transplant recipients: intercontinental prospective study of the infectious diseases working Party of the European Bone Marrow Transplantation Group. Clin Infect Dis. 2017;65(11): 1819-28.

7. van Duin D, van Delden C, Practice ASTIDCo. Multidrug-resistant gram-negative bacteria infections in solid organ transplantation. Am J Transplant. 2013;13(Suppl 4):31-41.

8. Liu T, Zhang Y, Wan Q. Methicillin-resistant Staphylococcus aureus bacteremia among liver transplant recipients: epidemiology and associated risk factors for morbidity and mortality. Infect Drug Resist. 2018;11:647-58.

9. Alexander BD, Petzold EW, Reller LB, Palmer SM, Davis RD, Woods CW, et al. Survival after lung transplantation of cystic fibrosis patients infected with Burkholderia cepacia complex. Am J Transplant. 2008;8(5):1025-30.

10. Bassetti M, Peghin M, Carnelutti A, Righi E, Merelli M, Ansaldi F, et al. Invasive Candida infections in liver transplant recipients: clinical features and risk factors for mortality. Transplant Direct. 2017;3(5):e156.

11. Azar MM, Turbett SE, Fishman JA, Pierce VM. Donor-derived transmission of Candida auris during lung transplantation. Clin Infect Dis. 2017;65(6):1040-2.

12. Lockhart SR, Etienne KA, Vallabhaneni S, Farooqi J, Chowdhary A, Govender NP, et al. Simultaneous emergence of multidrug-resistant Candida auris on 3 continents confirmed by whole-genome sequencing and epidemiological analyses. Clin Infect Dis. 2017;64(2):134-40.

13. Schelenz S, Hagen F, Rhodes JL, Abdolrasouli A, Chowdhary A, Hall A, et al. First hospital outbreak of the globally emerging Candida auris in a European hospital. Antimicrob Resist Infect Control. 2016;5:35.

14. Weinstein MP, Murphy JR, Reller LB, Lichtenstein KA. The clinical significance of positive blood cultures: a comprehensive analysis of 500 episodes of bacteremia and fungemia in adults. II. Clinical observations, with special reference to factors influencing prognosis. Rev Infect Dis. 1983;5(1):54-70.

15. Savinelli T, Parenteau S, Mermel LA. What happens when automated blood culture instrument detect growth but there are no technologists in the microbiology laboratory? Diagn Microbiol Infect Dis. 2004;48(3):173-4.

16. Cunney RJ, McNamara EB, Alansari N, Loo B, Smyth EG. The impact of blood culture reporting and clinical liaison on the empiric treatment of bacteraemia. J Clin Pathol. 1997;50(12):1010-2.

17. Buchan BW, Allen S, Burnham CA, McElvania TeKippe E, Davis T, Levi M, et al. Comparison of the next-generation Xpert MRSA/SA BC assay and the GeneOhm StaphSR assay to routine culture for identification of Staphylococcus aureus and methicillin-resistant S. aureus in positive-blood-culture broths. J Clin Microbiol. 2015;53(3):804-9.

18. Charnot-Katsikas A, Tesic V, Love N, Hill B, Bethel C, Boonlayangoor S, et al. Use of the accelerate Pheno system for identification and antimicrobial susceptibility testing of pathogens in positive blood cultures and impact on time to results and workflow. J Clin Microbiol. 2018;56(1):e01166-17.

19. Peker N, Couto N, Sinha B, Rossen JW. Diagnosis of bloodstream infections from positive blood cultures and directly from blood samples: recent developments in molecular approaches. Clin Microbiol Infect. 2018;24(9):944-55.

20. Korber F, Zeller I, Grunstaudl M, Willinger B, Apfalter P, Hirschl AM, et al. SeptiFast versus blood culture in clinical routine - a report on 3 years experience. Wien Klin Wochenschr. 2017;129(11-12):427-34. 
21. Wellinghausen N, Kochem AJ, Disque C, Muhl H, Gebert S, Winter J, et al. Diagnosis of bacteremia in whole-blood samples by use of a commercial universal 16S rRNA gene-based PCR and sequence analysis. J Clin Microbiol. 2009;47(9):2759-65.

22. Zboromyrska Y, Cillóniz C, Cobos-Trigueros N, Almela M, Hurtado JC, Vergara A, et al. Evaluation of the Magicplex ${ }^{\mathrm{TM}}$ Sepsis real-time test for the rapid diagnosis of bloodstream infections in adults. Front Cell Infect Microbiol. 2019;9:56.

23. Banerjee R, Teng CB, Cunningham SA, Ihde SM, Steckelberg JM, Moriarty JP, et al. Randomized trial of rapid multiplex polymerase chain reaction-based blood culture identification and susceptibility testing. Clin Infect Dis. 2015;61(7):1071-80.

24. Buehler SS, Madison B, Snyder SR, Derzon JH, Cornish NE, Saubolle MA, et al. Effectiveness of practices to increase timeliness of providing targeted therapy for inpatients with bloodstream infections: a laboratory medicine best practices systematic review and metaanalysis. Clin Microbiol Rev. 2016;29(1):59-103.

25. Walker T, Dumadag S, Lee CJ, Lee SH, Bender JM, Cupo Abbott J, et al. Clinical impact of laboratory implementation of Verigene BC-GN microarray-based assay for detection of gramnegative Bacteria in positive blood cultures. J Clin Microbiol. 2016;54(7):1789-96.

26. Messacar K, Parker SK, Todd JK, Dominguez SR. Implementation of rapid molecular infectious disease diagnostics: the role of diagnostic and antimicrobial stewardship. J Clin Microbiol. 2017;55(3):715-23.

27. Felsenstein S, Bender JM, Sposto R, Gentry M, Takemoto C, Bard JD. Impact of a rapid blood culture assay for gram-positive identification and detection of resistance markers in a pediatric hospital. Arch Pathol Lab Med. 2016;140(3):267-75.

28. Bauer KA, West JE, Balada-Llasat JM, Pancholi P, Stevenson KB, Goff DA. An antimicrobial stewardship program's impact with rapid polymerase chain reaction methicillin-resistant Staphylococcus aureus/S. aureus blood culture test in patients with S. aureus bacteremia. Clin Infect Dis. 2010;51(9):1074-80.

29. Doern CD. The slow march toward rapid phenotypic antimicrobial susceptibility testing: are we there yet? J Clin Microbiol. 2018;56(4):e1329-17.

30. Clancy CJ, Nguyen MH. Finding the "missing 50\%" of invasive candidiasis: how nonculture diagnostics will improve understanding of disease spectrum and transform patient care. Clin Infect Dis. 2013;56(9):1284-92.

31. Mizusawa M, Miller H, Green R, Lee R, Durante M, Perkins R, et al. Can multidrug-resistant Candida auris be reliably identified in clinical microbiology laboratories? J Clin Microbiol. 2017;55(2):638-40.

32. Neely LA, Audeh M, Phung NA, Min M, Suchocki A, Plourde D, et al. T2 magnetic resonance enables nanoparticle-mediated rapid detection of candidemia in whole blood. Sci Transl Med. 2013;5(182):182ra54.

33. Mylonakis E, Clancy CJ, Ostrosky-Zeichner L, Garey KW, Alangaden GJ, Vazquez JA, et al. $\mathrm{T} 2$ magnetic resonance assay for the rapid diagnosis of candidemia in whole blood: a clinical trial. Clin Infect Dis. 2015;60(6):892-9.

34. Clancy CJ, Pappas PG, Vazquez J, Judson MA, Kontoyiannis DP, Thompson GR 3rd, et al. Detecting infections rapidly and easily for Candidemia trial, Part 2 (DIRECT2): a prospective, multicenter study of the T2Candida panel. Clin Infect Dis. 2018;66(11):1678-86.

35. Neofytos D, Fishman JA, Horn D, Anaissie E, Chang CH, Olyaei A, et al. Epidemiology and outcome of invasive fungal infections in solid organ transplant recipients. Transpl Infect Dis. 2010;12(3):220-9.

36. Sexton DJ, Bentz ML, Welsh RM, Litvintseva AP. Evaluation of a new T2 magnetic resonance assay for rapid detection of emergent fungal pathogen Candida auris on clinical skin swab samples. Mycoses. 2018;61(10):786-90.

37. De Angelis G, Posteraro B, De Carolis E, Menchinelli G, Franceschi F, Tumbarello M, et al. T2Bacteria magnetic resonance assay for the rapid detection of ESKAPEc pathogens directly in whole blood. J Antimicrob Chemother. 2018;73(suppl_4):iv20-iv6. 
38. Falgenhauer L, Waezsada SE, Yao Y, Imirzalioglu C, Kasbohrer A, Roesler U, et al. Colistin resistance gene mcr-1 in extended-spectrum beta-lactamase-producing and carbapenemaseproducing Gram-negative bacteria in Germany. Lancet Infect Dis. 2016;16(3):282-3.

39. Harrison EM, Paterson GK, Holden MT, Larsen J, Stegger M, Larsen AR, et al. Whole genome sequencing identifies zoonotic transmission of MRSA isolates with the novel mecA homologue mecC. EMBO Mol Med. 2013;5(4):509-15.

40. Laabei M, Recker M, Rudkin JK, Aldeljawi M, Gulay Z, Sloan TJ, et al. Predicting the virulence of MRSA from its genome sequence. Genome Res. 2014;24(5):839-49.

41. Deurenberg RH, Bathoorn E, Chlebowicz MA, Couto N, Ferdous M, Garcia-Cobos S, et al. Application of next generation sequencing in clinical microbiology and infection prevention. J Biotechnol. 2017;243:16-24.

42. Fung M, Zompi S, Seng H, Hollemon D, Parham A, Hong DK, et al. Plasma cell-free DNA next-generation sequencing to diagnose and monitor infections in allogeneic hematopoietic stem cell transplant patients. Open Forum Infect Dis. 2018;5(12):ofy301.

43. Parize P, Muth E, Richaud C, Gratigny M, Pilmis B, Lamamy A, et al. Untargeted nextgeneration sequencing-based first-line diagnosis of infection in immunocompromised adults: a multicentre, blinded, prospective study. Clin Microbiol Infect. 2017;23(8):574.e1-6.

44. Gadsby NJ, Russell CD, McHugh MP, Mark H, Conway Morris A, Laurenson IF, et al. Comprehensive molecular testing for respiratory pathogens in community-acquired pneumonia. Clin Infect Dis. 2016;62(7):817-23.

45. Arvanitis M, Ziakas PD, Zacharioudakis IM, Zervou FN, Caliendo AM, Mylonakis E. PCR in diagnosis of invasive aspergillosis: a meta-analysis of diagnostic performance. J Clin Microbiol. 2014;52(10):3731-42.

46. Ascioglu S, Rex JH, de Pauw B, Bennett JE, Bille J, Crokaert F, et al. Defining opportunistic invasive fungal infections in immunocompromised patients with cancer and hematopoietic stem cell transplants: an international consensus. Clin Infect Dis. 2002;34(1):7-14.

47. Ullmann AJ, Aguado JM, Arikan-Akdagli S, Denning DW, Groll AH, Lagrou K, et al. Diagnosis and management of Aspergillus diseases: executive summary of the 2017 ESCMID-ECMM-ERS guideline. Clin Microbiol Infect. 2018;24(Suppl 1):e1-e38.

48. Patterson TF, Thompson GR 3rd, Denning DW, Fishman JA, Hadley S, Herbrecht R, et al. Executive summary: practice guidelines for the diagnosis and Management of Aspergillosis: 2016 update by the Infectious Diseases Society of America. Clin Infect Dis. 2016;63(4): 433-42.

49. Cruciani M, Mengoli C, Loeffler J, Donnelly P, Barnes R, Jones BL, et al. Polymerase chain reaction blood tests for the diagnosis of invasive aspergillosis in immunocompromised people. Cochrane Database Syst Rev. 2015;2015(10):CD009551.

50. White PL, Bretagne S, Klingspor L, Melchers WJ, McCulloch E, Schulz B, et al. Aspergillus PCR: one step closer to standardization. J Clin Microbiol. 2010;48(4):1231-40.

51. White PL, Mengoli C, Bretagne S, Cuenca-Estrella M, Finnstrom N, Klingspor L, et al. Evaluation of Aspergillus PCR protocols for testing serum specimens. J Clin Microbiol. 2011;49(11):3842-8.

52. White PL, Wingard JR, Bretagne S, Loffler J, Patterson TF, Slavin MA, et al. Aspergillus polymerase chain reaction: systematic review of evidence for clinical use in comparison with antigen testing. Clin Infect Dis. 2015;61(8):1293-303.

53. Chong GL, van de Sande WW, Dingemans GJ, Gaajetaan GR, Vonk AG, Hayette MP, et al. Validation of a new Aspergillus real-time PCR assay for direct detection of Aspergillus and azole resistance of Aspergillus fumigatus on bronchoalveolar lavage fluid. J Clin Microbiol. 2015;53(3):868-74.

54. Chong GM, van der Beek MT, von dem Borne PA, Boelens J, Steel E, Kampinga GA, et al. PCR-based detection of Aspergillus fumigatus Cyp51A mutations on bronchoalveolar lavage: a multicentre validation of the AsperGenius assay(R) in 201 patients with haematological disease suspected for invasive aspergillosis. J Antimicrob Chemother. 2016;71(12):3528-35. 
55. White PL, Posso RB, Barnes RA. Analytical and clinical evaluation of the PathoNostics AsperGenius assay for detection of invasive aspergillosis and resistance to azole antifungal drugs during testing of serum samples. J Clin Microbiol. 2015;53(7):2115-21.

56. White PL, Posso RB, Barnes RA. Analytical and clinical evaluation of the PathoNostics AsperGenius assay for detection of invasive aspergillosis and resistance to azole antifungal drugs directly from plasma samples. J Clin Microbiol. 2017;55(8):2356-66.

57. Dannaoui E, Gabriel F, Gaboyard M, Lagardere G, Audebert L, Quesne G, et al. Molecular diagnosis of invasive aspergillosis and detection of azole resistance by a newly commercialized PCR kit. J Clin Microbiol. 2017;55(11):3210-8.

58. Mikulska M, Furfaro E, De Carolis E, Drago E, Pulzato I, Borghesi ML, et al. Use of Aspergillus fumigatus real-time PCR in bronchoalveolar lavage samples (BAL) for diagnosis of invasive aspergillosis, including azole-resistant cases, in high risk haematology patients: the need for a combined use with galactomannan. Med Mycol. 2019;57:987.

59. White PL, Perry MD, Moody A, Follett SA, Morgan G, Barnes RA. Evaluation of analytical and preliminary clinical performance of Myconostica MycAssay Aspergillus when testing serum specimens for diagnosis of invasive aspergillosis. J Clin Microbiol. 2011;49(6): 2169-74.

60. Danylo A, Courtemanche C, Pelletier R, Boudreault AA. Performance of MycAssay Aspergillus DNA real-time PCR assay compared with the galactomannan detection assay for the diagnosis of invasive aspergillosis from serum samples. Med Mycol. 2014;52(6):577-83.

61. Torelli R, Sanguinetti M, Moody A, Pagano L, Caira M, De Carolis E, et al. Diagnosis of invasive aspergillosis by a commercial real-time PCR assay for Aspergillus DNA in bronchoalveolar lavage fluid samples from high-risk patients compared to a galactomannan enzyme immunoassay. J Clin Microbiol. 2011;49(12):4273-8.

62. Denis J, Forouzanfar F, Herbrecht R, Toussaint E, Kessler R, Sabou M, et al. Evaluation of two commercial real-time PCR kits for Aspergillus DNA detection in Bronchoalveolar lavage fluid in patients with invasive pulmonary aspergillosis. J Mol Diagn. 2018;20(3):298-306.

63. Elges S, Arnold R, Liesenfeld O, Kofla G, Mikolajewska A, Schwartz S, et al. Prospective evaluation of the SeptiFAST multiplex real-time PCR assay for surveillance and diagnosis of infections in haematological patients after allogeneic stem cell transplantation compared to routine microbiological assays and an in-house real-time PCR method. Mycoses. 2017;60(12): $781-8$.

64. Lamoth F, Jaton K, Prod'hom G, Senn L, Bille J, Calandra T, et al. Multiplex blood PCR in combination with blood cultures for improvement of microbiological documentation of infection in febrile neutropenia. J Clin Microbiol. 2010;48(10):3510-6.

65. Steinmann J, Buer J, Rath PM, Paul A, Saner F. Invasive aspergillosis in two liver transplant recipients: diagnosis by SeptiFast. Transpl Infect Dis. 2009;11(2):175-8.

66. White PL, Hibbitts SJ, Perry MD, Green J, Stirling E, Woodford L, et al. Evaluation of a commercially developed semiautomated PCR-surface-enhanced raman scattering assay for diagnosis of invasive fungal disease. J Clin Microbiol. 2014;52(10):3536-43.

67. Rath PM, Steinmann J. Overview of commercially available PCR assays for the detection of Aspergillus spp. DNA in patient samples. Front Microbiol. 2018;9:740.

68. Verweij PE, Chowdhary A, Melchers WJ, Meis JF. Azole resistance in Aspergillus fumigatus: can we retain the clinical use of Mold-active antifungal azoles? Clin Infect Dis. 2016;62(3): $362-8$.

69. Denning DW, Venkateswarlu K, Oakley KL, Anderson MJ, Manning NJ, Stevens DA, et al. Itraconazole resistance in Aspergillus fumigatus. Antimicrob Agents Chemother. 1997;41(6): 1364-8.

70. Verweij PE, van de Sande-Bruisma N, Kema GH, Melchers WJ. [Azole resistance in Aspergillus fumigatus in the Netherlands - increase due to environmental fungicides?]. Ned Tijdschr Geneeskd 2012;156(25):A4458. 
71. Wiederhold NP, Gil VG, Gutierrez F, Lindner JR, Albataineh MT, McCarthy DI, et al. First detection of TR34 L98H and TR46 Y121F T289A Cyp51 mutations in Aspergillus fumigatus isolates in the United States. J Clin Microbiol. 2016;54(1):168-71.

72. Koo S, Thomas HR, Daniels SD, Lynch RC, Fortier SM, Shea MM, et al. A breath fungal secondary metabolite signature to diagnose invasive aspergillosis. Clin Infect Dis. 2014;59(12):1733-40.

73. Acharige MJT, Koshy S, Ismail N, Aloum O, Jazaerly M, Astudillo CL, et al. Breath-based diagnosis of fungal infections. J Breath Res. 2018;12(2):027108.

74. Curetis. 2019. p. https://www.curetisusa.com/unyvero-system/

75. Hammond SP, Gagne LS, Stock SR, Marty FM, Gelman RS, Marasco WA, et al. Respiratory virus detection in immunocompromised patients with FilmArray respiratory panel compared to conventional methods. J Clin Microbiol. 2012;50(10):3216-21.

76. Affolter K, Schumann DM, Tamm M, Jahn K, Siebeneichler A, Junker L, et al. Multiplex PCR on the Bronchoalveolar lavage fluid of immunocompromised patients. Chest. 2018;154(3): $722-5$.

77. Lewandowska DW, Schreiber PW, Schuurmans MM, Ruehe B, Zagordi O, Bayard C, et al. Metagenomic sequencing complements routine diagnostics in identifying viral pathogens in lung transplant recipients with unknown etiology of respiratory infection. PLoS One. 2017;12(5): 0177340.

78. Langelier C, Zinter MS, Kalantar K, Yanik GA, Christenson S, O’Donovan B, et al. Metagenomic sequencing detects respiratory pathogens in hematopoietic cellular transplant patients. Am J Respir Crit Care Med. 2018;197(4):524-8.

79. Li H, Gao H, Meng H, Wang Q, Li S, Chen H, et al. Detection of pulmonary infectious pathogens from lung biopsy tissues by metagenomic next-generation sequencing. Front Cell Infect Microbiol. 2018;8:205.

80. Xie H, Flygare S, Mei Y, Matsuzaki H, Yandell M, Graf EH. Detection of Previously Missed Pathogens in Immunocompromised Children with Pneumonia by a Fully-Validated NextGeneration Sequencing Test. A27 BRONCHIECTASIS AND LUNG INFECTION. p. A7561-A.

81. Glaser CA, Honarmand S, Anderson LJ, Schnurr DP, Forghani B, Cossen CK, et al. Beyond viruses: clinical profiles and etiologies associated with encephalitis. Clin Infect Dis. 2006;43(12):1565-77.

82. Leber AL, Everhart K, Balada-Llasat JM, Cullison J, Daly J, Holt S, et al. Multicenter evaluation of BioFire FilmArray meningitis/encephalitis panel for detection of Bacteria, viruses, and yeast in cerebrospinal fluid specimens. J Clin Microbiol. 2016;54(9):2251-61.

83. Chang D, Okulicz JF, Nielsen LE, White BK. A tertiary care Center's experience with novel molecular meningitis/encephalitis diagnostics and implementation with antimicrobial stewardship. Mil Med. 2018;183(1-2):e24-e7.

84. O'Halloran JA, Franklin A, Lainhart W, Burnham CA, Powderly W, Dubberke E. Pitfalls associated with the use of molecular diagnostic panels in the diagnosis of Cryptococcal meningitis. Open Forum Infect Dis. 2017;4(4):ofx242.

85. Walker M, Sheets J, Hamer D, O'Neal C. Performance of the Biofire Filmarray meningitis/encephalitis panel in Cryptococcal meningitis diagnosis. Open Forum Infect Dis. 2018;5(Supplement 1):S599.

86. Lipowski D, Popiel M, Perlejewski K, Nakamura S, Bukowska-Osko I, Rzadkiewicz E, et al. A cluster of fatal tick-borne encephalitis virus infection in organ transplant setting. J Infect Dis. 2017;215(6):896-901.

87. Palacios G, Druce J, Du L, Tran T, Birch C, Briese T, et al. A new arenavirus in a cluster of fatal transplant-associated diseases. N Engl J Med. 2008;358(10):991-8.

88. Bunnapradist S, Neri L, Wong W, Lentine KL, Burroughs TE, Pinsky BW, et al. Incidence and risk factors for diarrhea following kidney transplantation and association with graft loss and mortality. Am J Kidney Dis. 2008;51(3):478-86. 
89. Mengelle C, Mansuy JM, Prere MF, Grouteau E, Claudet I, Kamar N, et al. Simultaneous detection of gastrointestinal pathogens with a multiplex Luminex-based molecular assay in stool samples from diarrhoeic patients. Clin Microbiol Infect. 2013;19(10):E458-65.

90. Coste JF, Vuiblet V, Moustapha B, Bouin A, Lavaud S, Toupance O, et al. Microbiological diagnosis of severe diarrhea in kidney transplant recipients by use of multiplex PCR assays. J Clin Microbiol. 2013;51(6):1841-9.

91. Liesman RM, Binnicker MJ. The role of multiplex molecular panels for the diagnosis of gastrointestinal infections in immunocompromised patients. Curr Opin Infect Dis. 2016;29(4):359-65.

92. Atlas C, Aad G, Abajyan T, Abbott B, Abdallah J, Abdel Khalek S, et al. Jet energy measurement and its systematic uncertainty in proton-proton collisions at [Formula: see text] TeV with the ATLAS detector. Eur Phys J C Part Fields. 2015;75:17.

93. Buss SN, Leber A, Chapin K, Fey PD, Bankowski MJ, Jones MK, et al. Multicenter evaluation of the BioFire FilmArray gastrointestinal panel for etiologic diagnosis of infectious gastroenteritis. J Clin Microbiol. 2015;53(3):915-25.

94. Spina A, Kerr KG, Cormican M, Barbut F, Eigentler A, Zerva L, et al. Spectrum of enteropathogens detected by the FilmArray GI Panel in a multicentre study of communityacquired gastroenteritis. Clin Microbiol Infect. 2015;21(8):719-28.

95. Wessels E, Rusman LG, van Bussel MJ, Claas EC. Added value of multiplex Luminex Gastrointestinal Pathogen Panel (xTAG(R) GPP) testing in the diagnosis of infectious gastroenteritis. Clin Microbiol Infect. 2014;20(3):O182-7.

96. McMillen T, Lee YJ, Kamboj M, Babady NE. Limited diagnostic value of a multiplexed gastrointestinal pathogen panel for the detection of adenovirus infection in an oncology patient population. J Clin Virol. 2017;94:37-41.

97. Greninger AL. The challenge of diagnostic metagenomics. Expert Rev Mol Diagn. 2018;18(7):605-15.

98. Simner PJ, Miller S, Carroll KC. Understanding the promises and hurdles of metagenomic next-generation sequencing as a diagnostic tool for infectious diseases. Clin Infect Dis. 2018;66(5):778-88.

99. Guinea J, Padilla C, Escribano P, Munoz P, Padilla B, Gijon P, et al. Evaluation of MycAssay Aspergillus for diagnosis of invasive pulmonary aspergillosis in patients without hematological cancer. PLoS One. 2013;8(4):e61545.

100. Aslan M, Oz Y, Aksit F, Akay OM. Potential of polymerase chain reaction and galactomannan for the diagnosis of invasive aspergillosis in patients with febrile neutropenia. Mycoses. 2015;58(6):343-9.

101. Lass-Florl C, Follett SA, Moody A, Denning DW. Detection of Aspergillus in lung and other tissue samples using the MycAssay Aspergillus real-time PCR kit. Can J Microbiol. 2011;57(9):765-8.

102. Simner PJ, Uhl JR, Hall L, Weber MM, Walchak RC, Buckwalter S, et al. Broad-range direct detection and identification of fungi by use of the PLEX-ID PCR-electrospray ionization mass spectrometry (ESI-MS) system. J Clin Microbiol. 2013;51(6):1699-706.

103. Wilson MR, Naccache SN, Samayoa E, Biagtan M, Bashir H, Yu G, et al. Actionable diagnosis of neuroleptospirosis by next-generation sequencing. N Engl J Med. 2014;370(25):2408-17.

104. Brown JR, Morfopoulou S, Hubb J, Emmett WA, Ip W, Shah D, et al. Astrovirus VA1/HMO$\mathrm{C}$ : an increasingly recognized neurotropic pathogen in immunocompromised patients. Clin Infect Dis. 2015;60(6):881-8.

105. Naccache SN, Peggs KS, Mattes FM, Phadke R, Garson JA, Grant P, et al. Diagnosis of neuroinvasive astrovirus infection in an immunocompromised adult with encephalitis by unbiased next-generation sequencing. Clin Infect Dis. 2015;60(6):919-23.

106. Christopeit M, Grundhoff A, Rohde H, Belmar-Campos C, Grzyska U, Fiehler J, et al. Suspected encephalitis with Candida tropicalis and Fusarium detected by unbiased RNA sequencing. Ann Hematol. 2016;95(11):1919-21. 
107. Lum SH, Turner A, Guiver M, Bonney D, Martland T, Davies E, et al. An emerging opportunistic infection: fatal astrovirus (VA1/HMO-C) encephalitis in a pediatric stem cell transplant recipient. Transpl Infect Dis. 2016;18(6):960-4.

108. Salzberg SL, Breitwieser FP, Kumar A, Hao H, Burger P, Rodriguez FJ, et al. Next-generation sequencing in neuropathologic diagnosis of infections of the nervous system. Neurol Neuroimmunol Neuroinflamm. 2016;3(4):e251.

109. Sato M, Kuroda M, Kasai M, Matsui H, Fukuyama T, Katano H, et al. Acute encephalopathy in an immunocompromised boy with astrovirus-MLB1 infection detected by next generation sequencing. J Clin Virol. 2016;78:66-70.

110. Morfopoulou S, Brown JR, Davies EG, Anderson G, Virasami A, Qasim W, et al. Human coronavirus OC43 associated with fatal encephalitis. N Engl J Med. 2016;375(5):497-8.

111. Wilson MR, Zimmermann LL, Crawford ED, Sample HA, Soni PR, Baker AN, et al. Acute West Nile virus meningoencephalitis diagnosed via metagenomic deep sequencing of cerebrospinal fluid in a renal transplant patient. Am J Transplant. 2017;17(3):803-8.

112. Murkey JA, Chew KW, Carlson M, Shannon CL, Sirohi D, Sample HA, et al. Hepatitis E virus-associated meningoencephalitis in a lung transplant recipient diagnosed by clinical metagenomic sequencing. Open Forum Infect Dis. 2017;4(3):ofx121.

113. Morfopoulou S, Mee ET, Connaughton SM, Brown JR, Gilmour K, Chong WK, et al. Deep sequencing reveals persistence of cell-associated mumps vaccine virus in chronic encephalitis. Acta Neuropathol. 2017;133(1):139-47. 